\title{
Current issues in fish welfare
}

\section{review paper}

Huntingford, F.A.; Adams, C.; Braithwaite, V.A.; Kadri, S.; Pottinger, T.G.; Sandøe, Peter; Turnbull, J.F.

Published in:

Journal of Fish Biology

DOI:

10.1111/j.0022-1112.2006.001046.x

Publication date:

2006

Document version

Publisher's PDF, also known as Version of record

Citation for published version (APA):

Huntingford, F. A., Adams, C., Braithwaite, V. A., Kadri, S., Pottinger, T. G., Sandøe, P., \& Turnbull, J. F. (2006).

Current issues in fish welfare: review paper. Journal of Fish Biology, 68(2), 332-372.

https://doi.org/10.1111/j.0022-1112.2006.001046.x 


\title{
Review paper: Current issues in fish welfare ${ }^{1}$
}

\author{
F. Huntingford*, C. Adams*, V. A. Braithwaite+, S. Kadri*, T. G. Pottinger++, P. Sandøe** \& J. F. \\ Turnbull***
}

*Fish Biology Group, Institute of Biomedical \& Life Sciences, Graham Kerr Building, University of Glasgow, Glasgow, G12 8QQ, UK. +Institute of Evolutionary Biology, University of Edinburgh, Kings Buildings, Edinburgh. EH9 3JT ++ NERC Centre for Ecology \& Hydrology, Lancaster Environment Centre, Library Avenue, Bailrigg, Lancaster, LA1 4AP ** Centre for Bioethics and Risk Assessment, Royal Veterinary and Agricultural University, Copenhagen ***Institute of Aquaculture, University of Stirling, Stirling, FK9 4LA

\begin{abstract}
Human beings may affect the welfare of fish through fisheries, aquaculture and a number of other activities. There is no agreement on just how to weigh the concern for welfare of fish against the human interests involved, but ethical frameworks exist that suggest how this might be approached.

Different definitions of animal welfare focus on an animal's condition, on its subjective experience of that condition and/or on whether it can lead a natural life. These provide different, legitimate, perspectives, but the approach taken in this paper is to focus on welfare as the absence of suffering.

An unresolved and controversial issue in discussions about animal welfare is whether non-human animals exposed to adverse experiences such as physical injury or confinement experience what humans would call suffering. The neocortex, which in humans is an important part of the neural mechanism that generates the subjective experience of suffering, is lacking in fish and non-mammalian animals, and it has been argued that its absence in fish indicates that fish cannot suffer. However, a strong alternative view is that complex animals with sophisticated behaviour, such as fish, probably have the capacity for suffering, though this may be different in degree and kind from the human experience of this state.

Recent empirical studies support this view and show that painful stimuli are, at least, strongly aversive to fish. Consequently, injury or experience of other harmful conditions is a cause for concern in terms of welfare of individual fish. There is also growing evidence that fish can experience fear-like states and that they avoid situations in which they have experienced adverse conditions.

\footnotetext{
${ }^{1}$ The reference of the printed version is:

Felicity Huntingford, Colin Adams, Victoria A. Braithwaite, Sunil Kadri, Tom G. Pottinger, Peter Sandøe \& James F.

Turnbull. (2006): Review paper: Current issues in fish welfare. Journal of Fish Biology 68: 332-372.

The definitive version is available at

http://onlinelibrary.wiley.com/doi/10.1111/j.0022-1112.2006.001046.x/abstract
} 
Human activities that potentially compromise fish welfare include anthropogenic changes to the environment, commercial fisheries, recreational angling, aquaculture, ornamental fish keeping and scientific research. The resulting harm to fish welfare is a cost that must be minimised and weighed against the benefits of the activity concerned.

Wild fish naturally experience a variety of adverse conditions, from attack by predators or conspecifics to starvation or exposure to poor environmental conditions. This does not make it acceptable for humans to impose such conditions on fish, but it does suggest that fish will have mechanisms to cope with these conditions and reminds us that pain responses are in some cases adaptive (for example, suppressing feeding when injured).

In common with all vertebrates, fish respond to environmental challenges with a series of adaptive neuro-endocrine adjustments that are collectively termed the stress response. These in turn induce reversible metabolic and behavioural changes that make the fish better able to overcome or avoid the challenge and are undoubtedly beneficial, in the short-term at least.

In contrast, prolonged activation of the stress response is damaging and leads to immuno-suppression, reduced growth and reproductive dysfunction. Indicators associated with the response to chronic stress (physiological endpoints, disease status and behaviour) provide a potential source of information on the welfare status of a fish. The most reliable assessment of well-being will be obtained by examining a range of informative measures and statistical techniques are available that enable several such measures to be combined objectively.

A growing body of evidence tells us that many human activities can harm fish welfare, but that the effects depend on the species and life history stage concerned and are also context-dependent. For example, in aquaculture, adverse effects related to stocking density may be eliminated if good water quality is maintained. At low densities, bad water quality may be less likely to arise whereas social interactions may cause greater welfare problems.

A number of key differences between fish and birds and mammals have important implications for their welfare. Fish do not need to fuel a high body temperature, so the effects of food deprivation on welfare are not so marked. For species that live naturally in large shoals, low rather than high densities may be harmful. On the other hand, fish are in intimate contact with their environment through the huge surface area of their gills, so they are vulnerable to poor water quality and water borne pollutants.

Extrapolation between taxa is dangerous and general frameworks for ensuring welfare in other vertebrate animals need to be modified before they can be usefully applied to fish.

The scientific study of fish welfare is at an early stage compared with work on other vertebrates and a great deal of what we need to know is yet to be discovered. However, it is clearly the case that fish, though different from birds and mammals, are sophisticated animals, far removed from unfeeling creatures with a 15 second memory of popular misconception. A heightened appreciation of these points 
in those who exploit fish and in those who seek to protect them would go a long way towards improving fish welfare.

Key words: Fish, welfare, stress, pain, fisheries, aquaculture, ornamental fish.

\section{Introduction}

The aim of this review, which arose from a briefing paper prepared for the Fisheries Society of the British Isles (http://www.le.ac.uk/biology/fsbi/briefing.html), is to give a broad overview of current understanding on a number of issues relating to fish welfare, an area of increasing public concern. The term "fish" includes animals of very different taxonomic status and in this review we mostly consider teleost fish, since these have been the subject of almost all recent research into fish welfare. A broad approach necessarily precludes in-depth, exhaustive coverage of all the relevant issues, but many of these issues have been the subject of recent published reviews and we cite these in the relevant sections. We briefly address what welfare means, why it matters and how welfare science relates to the philosophical discipline of ethics, before considering human activities that may compromise fish welfare and how welfare might be measured. We concentrate on the impact of human activity on welfare at the level of individuals, as opposed to populations, species or ecosystems and address the experiences of living animals (up to and including the point of slaughter) and not the question of whether it is right to kill animals.

To discuss animal welfare objectively, we need a definition and this is not easy to produce because the concept is complex and the word is used in a number of different ways (Dawkins, 1998; Appleby, 1999). Most definitions fall into one of three broad categories (Duncan \& Fraser, 1997; Fraser et al., 1997), none of which is right or wrong from a scientific point of view; rather they express different ideals about what we should be concerned about in our dealings with animals:

Feelings-based definitions are set in terms of subjective mental states. Here, the requirement for good welfare is that the animal should feel well, being free from negative experiences such as pain or fear and having access to positive experiences, such as companionship in the case of social species. This use of the term welfare obviously depends on the animal concerned having conscious subjective experiences and our ability to interpret such experiences, controversial points (Dawkins, 1998) that are discussed below.

Function-based definitions centre on an animal's ability to adapt to its present environment. Here good welfare requires that the animal be in good health with its biological systems (and particularly those involved 
in coping with challenges to stasis) functioning appropriately and not being forced to respond beyond their capacity. This definition is based on things that are relatively easy to observe and measure.

Nature-based definitions arise from the view that each species of animal has an inherent biological nature that it must express. Here good welfare requires that the animal is able to lead a natural life and express its natural behaviour. This approach, which reflects a view that what is natural, is inherently good, focuses on something we can measure, namely what animals do in the wild and in captivity.

Because suffering, health problems and impairment of natural behaviour often accompany each other, in many cases these three approaches will reach the same conclusions. Chickens (Gallus domesticus) are strongly motivated to build nests (as opposed to having access to a completed nest) and will work hard for the opportunity to build (Hughes et al., 1989); arguably then, nest-building reflects a behavioural need that must be met if the chicken's welfare is not to be compromised. However, in some cases different conclusions about whether welfare is compromised will follow from the different definitions. For example, much behaviour of wild animals is shown in response to adverse conditions (as when fleeing from a predator), but it is hard to argue that feelings of suffering will occur if these responses are not evoked. In other cases, animals may be highly motivated to perform an action independent of its consequences. Their welfare may be compromised if they are deprived of the opportunity to do so, but this is not necessarily the case and it may be difficult to decide whether the different approaches lead to the same conclusion. For example, wild Atlantic salmon (Salmo salar) migrate long distances at sea. If this happens because fish leave an area when the local food supply is poor and stop swimming when they find food, there is no reason to believe that farmed salmon will be frustrated when they are prevented from migrating, provided they have plenty of food. If they are simply motivated to swim, then swimming in large circles may be sufficient to avoid such frustration. On the other hand, if they have an instinctive drive to move to new areas regardless of food supply, confinement in cages might well lead to suffering, even though fish are able to swim continuously.

It is, therefore, important to state clearly what definition of animal welfare is being used (Appleby \& Sandøe, 2002). In this article, we adopt a feelings-based approach that focuses on animal suffering that is on more-orless intense unpleasant mental or physical states felt by the animal. One important complicating factor is that the occurrence of unpleasant states does not by itself imply suffering. Such states are an unavoidable part of normal animal life and often serve as signals or behavioural prompts that help the animals satisfy their biological needs. Sometimes, negative experiences are compensated for by corresponding positive experiences, so suffering may be defined as prolonged experience of unpleasant mental states. 


\section{Science, ethics and welfare}

Humans may affect the welfare of fish in many ways, through fisheries, aquaculture, sports fishing, scientific research or the keeping of fish as a hobby activity, all of which have associated benefits (see Section 8). There is therefore every reason to seek a better empirical understanding of fish welfare and to give careful thought to how we should weigh the welfare of fish against the interests of humans when these are in conflict. Their disciplinary training gives biologists a special role to play in the first of these aims; but not in the second, which is the job of the moral philosopher/ethicist. To put it another way, biologists may be able to tell us whether the welfare of fishes is compromised by a certain human activity and even perhaps by how much, but normally they have neither the expertise needed for nor the responsibility of deciding whether that human activity is justified. However, welfare biology and the ethical analyses of animal use share the goal of elucidating the relationship between humans and other animals (Fraser, 1999). We spell out very briefly here some frameworks that ethicists, typically scholars with a background in philosophy, have developed to guide clear thinking on the complex moral issues of whether and when humans have the right to make use of animals for food production, sports and hobbies (e.g. Rollin, 1993; Sandøe et al., 1997; Heeger \& Brom, 2001). It should be noted that, like the biologist, the ethicist does not have the right to decide what is right or wrong; rather their expertise allows them to deliver thoughts that may be relevant when we try to think clearly about these issues.

Thinking clearly is not always the fashion when it comes to animal issues. Often feelings without much thought seem to prevail and this has its problems. The first problem of being led by one's feelings rather than approaching matters through ethical theory is simply that people's feelings about animal use are often unstable or ambivalent and so cannot be relied upon as a rational guide. This immediately leads to a second problem, namely that ambivalence encourages double standards that are both morally objectionable and logically indefensible. The third problem is perhaps the most serious. It is clear that, at present, we are engaged in the West in an increasingly serious debate about the rights and wrongs of animal use. As long as they merely press their intuitively held beliefs, people on either side of the debate about making use of fish as a resource will not be able to communicate effectively. These beliefs are often sincere and strongly held, but they can be extremely difficult to understand and highly resistant to change. The ideal of meaningful and transparent discussion leading to mutual understanding is attainable, however, because people's gut feelings about matters are very often based on underlying ethical assumptions and theories, which are more susceptible to rational assessment than the individual beliefs to which they give rise. The suggestion we wish to make here, then, is that if lay people and scientists are willing to think a little about fundamental ethical theory, they will have a much greater prospect of communicating with one another effectively, articulating their convictions in a coherent manner, and perhaps even reaching a compromise upon which all can agree. 
Moral philosophers distinguish a number of types of ethical theory, and in principle any of these might underlie a person's views about animal use by humans. Here we will discuss three prominent theoretical positions: contractarianism, utilitarianism and rights views. These have been selected because they have direct and obvious implications for the ongoing debate over animal use.

\section{Contractarianism}

Why should we act morally? This is a central question in moral philosophy, and one to which the contractarian gives a straightforward answer: one should act morally because it is in one's self-interest to do so. The outlook underlying contractarianism is egoism. According to the egoist, when one is obliged to show consideration for other people this is really for one's own sake. In general, by respecting the rules of morality one contributes to the maintenance of a society that is essential to one's own welfare. The moral rules are thus those that best serve the self-interest of all members of the society. Contractarian morality is confined to those individuals who can 'contract in' to the moral community, so it is important to define who these members are. On this topic, Narveson (1983) writes: "On the contract view of morality, morality is a sort of agreement among rational, independent, self-interested persons, persons who have something to gain from entering into such an agreement..."

A major feature of this view of morality is that it explains why we have it and who is party to it. We have it for reasons of long-term self-interest, and parties to it include all and only those who have both of the following characteristics: 1) they stand to gain by subscribing to it, at least in the long run, compared with not doing so, and 2) they are capable of entering into (and keeping) an agreement... Given these requirements, it will be clear why animals do not have rights, for there are evident shortcomings on both scores. On the one hand, humans have nothing generally to gain by voluntarily refraining from (for instance) killing animals or 'treating them as mere means'. On the other, animals cannot generally make agreements with us anyway, even if we wanted to have them do so..."

On this view there is clearly a morally relevant difference between ones relationship to other human beings and ones relation to animals. We are dependent on the respect and cooperation of other people. If we treat our fellow humans badly, they will respond by treating us badly. By contrast, the animal community will not strike back if, let us say, we use some of its members to hunt or fish for the fun of it. From an egoistic point of view we need only treat the animals well enough for them to be fit for our own purposes. In any case, as Narveson points out, non-human animals cannot enter into a contract, or agreement, governing future conduct, so they cannot join the moral community. 
For the contractarian, since neither animal suffering nor the killing of animals is an ethical problem per se, any kind of animal use is in itself ethically acceptable. The lack of standing of animals in the moral community does not necessarily mean that the way animals are treated is irrelevant from the contractarian point of view: if people like animals, for example, and dislike the practice of their being used in this or that way, animal use can become an ethical issue, because it is in a person's interests to get what he or she likes. Nevertheless the contractarian view of animals is highly anthropocentric, since any rights to protection animals have will always be dependent on human concern. Inevitably, we tend to like some types of animal more than others and are more troubled by the suffering of our favourite sorts of animal. Hence, levels of protection will differ across different varieties of animal.

The contractarian view accords with certain attitudes to animal treatment that are prevalent in our society. Thus it serves to explain why legislation, allegedly for the protection of animals, usually protects the animals that matter most to humans, such as cats and dogs. Contractarianism can, however, seem inadequate. Can it really be correct to hold that causing animals to suffer, even for a trivial reason, or for no particular reason, is morally straightforward as long as no human being is bothered by the relevant conduct? Many would want to insist that it is immoral as such to cause another to suffer for little or no reason, whether one's victim is a human being or an animal. An ethical theory that captures this insistence is utilitarianism.

Typically people have less strong feelings about fish and therefore fish are less well protected than other kinds of animals. According to this approach, one might have legitimate concern for the welfare of fish in an ornamental tank, since the pleasure one gets from them might be reduced if the were in a poor state of welfare. Fish biologists might have a concern for the welfare of their subjects, since poor welfare may well equate to poor science. In both cases we need to be able to recognise and measure good versus poor welfare.

\section{Utilitarianism}

According to the utilitarian, the interests of every individual affected by an action count morally and deserve equal consideration. In utilitarian writings the notion of an interest is usually defined in terms of "the capacity for suffering and/or enjoyment or happiness" (Singer, 1989). Thus individuals have an interest in acts that will enhance their enjoyment or reduce their suffering. From this it follows, of course, that all sentient beings, human and non-human, have interests. And since for the utilitarian all interests count morally and deserve equal consideration, this implies that the impact of one's actions on all sentient creatures, including animals, is a matter of moral concern. Thus Singer (1989) writes: "Many philosophers have proposed the principle of equal consideration of interests, in some form or other, as a basic moral principle; but ... not many of them have recognized that this principle applies to members of other species as well as to our own. ...If a being suffers, there can be no moral justification for refusing to take that suffering 
into consideration. No matter what the nature of the being, the principle of equality requires that its suffering be counted equally with the like suffering — in so far as rough comparisons can be made — of any other being."

For the utilitarian, then, ethical decisions require us to strike the most favourable balance of benefits and costs for all the sentient individuals affected by what we do. Doing the right thing, according to the utilitarian, is not only a matter of doing what is optimal. It is also essential to do something rather than nothing: if something can be done to increase well-being, we have a duty to do it. This utilitarian duty to act always to bring about improvements has important consequences for society. In contemporary Western society we have a general tendency to give ourselves priority over animals. A utilitarian will regard this tendency as essentially wrong. However, the anthropocentric outlook is obviously well established, and in view of this it may well be that, for the time being at least, any attempt to ensure that sentient animals are accorded the same status as human beings is bound to fail. It may be that the best thing a utilitarian can do is to secure higher levels of animal welfare within the current system. It may here be relevant to mention that the Journal of Fish Biology requires its authors to refer to the Association for the Study of Animal Behaviour's Guidelines for the Use of Animals in Research (2001), which are firmly based in such a semiutilitarian approach.

The overwhelming majority of domestic animals are kept for food production. Most are kept under restrictive conditions in which basic behavioural or physiological needs are thwarted. Laying hens, for example, are commonly kept in battery cages where they cannot perform strongly motivated nesting behaviour before egg laying and where the restriction of their movement results in bone brittleness and a high incidence of broken bones. Farmed fish too are kept at high densities. Whether or not their physiological and behavioural needs are thwarted is so far not clear (see section 6). Naturally, such costs must be weighed against the benefit, to human beings, of access to cheap meat and eggs. But given that the average citizen in the developed world consumes far more protein than is physiologically necessary, and often more animal fat than is healthy, low-cost meat cannot be considered a vital human interest.

What all utilitarians agree on, however, is the methodological precept that ethical decisions concerning animal use require us to balance the harm we do to the affected animals against the benefits we derive for humans and other animals. Interestingly, this very precept (i.e. the notion that we can work out what is ethical by trading off one set of interests against another) has been attacked by some moral philosophers. The allegation is that such trade-offs violate the rights of the individuals whose interests are in the moral balance. To get clearer about this, we need to turn to rights theories. 


\section{Rights views}

There is an obvious sense in which, in focusing on overall improvements in welfare, the utilitarian treats sentient beings as mere instruments. The utilitarian believes that it is ethically justifiable to sacrifice the welfare of one individual where this sacrifice is outweighed by connected gains in welfare. Rights theorists object to this, holding that it is always unacceptable to treat a sentient being merely as a means to obtain a goal. Historically, rights theory is associated with the eighteenth-century German philosopher, Immanuel Kant. In Kant's view, human beings have "an intrinsic worth, i.e. dignity" and should therefore be treated "always as an end and never as a means only". Clearly this view is at variance with the utilitarian's willingness to sacrifice one individual's welfare where this leads overall to welfare gains. Kant himself confined the right to be treated as an end to human beings, but later rights theorists, such as the American philosopher Tom Regan (1989), have argued that the principle of dignity should be extended to animals. Thus "...attempts to limit its scope to humans only can be shown to be rationally defective. Animals, it is true, lack many of the abilities humans possess. They can't read, do higher mathematics, build a bookcase, or make baba ghanoush. Neither can many human beings, however, and yet we don't (and shouldn't) say that they (these humans) therefore have less inherent value, less of a right to be treated with respect, than do others. It is the similarities between those human beings who most clearly, most non-controversially have such value (the people reading this, for example), and not our differences that matter most. The really crucial, basic similarity is simply this: we are each of us the experiencing subject of a life, a conscious creature having an individual welfare that has importance to us whatever our usefulness to others. We want and prefer things, believe and feel things, recall and expect things. All these dimensions of our life, including our pleasure and pain, our enjoyment and suffering, our satisfaction and frustration, our continued existence or our untimely death - all make a difference to the quality of our life as lived, as experienced, by us as individuals. As the same is true of those animals that concern us (the ones that are eaten and trapped, for example), they too must be viewed as the experiencing subjects of a life, with inherent value of their own."

What implications does the rights view have for animal use? Obviously, the answer to this question will depend on whether we are prepared to go along with Regan and ascribe rights to animals. If we refuse to take this step, rights theory will have little to tell us about animal use. However if we allow that animals possess intrinsic dignity and have rights various things will follow. To begin with, the balancing of human benefits against animal suffering that has been central in our discussion so far becomes to some extent a background issue. No benefit can justify disrespect for the rights of an individual, human or animal.

Categorical abolitionism of this sort probably goes further in its attempt to limit the utilitarian trade-offs than most of us would consider necessary. After all, weighing costs against benefits and seeking what is best overall, in private decisions is part of our daily life. We expect others (for example, employers and 
government bodies) to do the same. In all this, we accept that we are not treated, and do not treat others, purely as ends. On the other hand, most people would presumably allow that certain rights are sacrosanct, and that there are limits to the extent to which an individual can be sacrificed for an overall benefit. Only (what we might call) a moderate rights view is likely to command widespread acceptance.

How would such a moderate view apply to animal use? The detail would depend on what rights we take to be fundamental. The right to life (or more accurately, the right not to be killed) is often regarded as basic. Curiously, however, this does not appear to be a basic right that people would ascribe to animals: after all, most of us happily eat animals that have been killed just for this purpose. Something like a right to protection from suffering, or significant suffering, seems to be much more promising. We might agree that all animals should be protected from suffering if this involves intense or prolonged pain or distress that the animal cannot control. Fish biologists have a part to play in this debate, since they can help to develop husbandry practices that do not infringe the rights of fish, on this moderated rights view.

An assumption underlying the previous discussion is, of course, that fish are sentient beings. This matters both for the utilitarian, for whom the ability to suffer and feel pleasure is the key criterion of moral consideration and for the adherents of the rights view, who would typically claim that only sentient beings can be bearers of rights. However, this assumption is not uncontroversial especially in the case of nonmammalian animals, as will become clear in the next section.

\section{Welfare, suffering and the perception of pain and fear in fish}

In the light of the definition of welfare used here (based on absence of suffering), a major unresolved issue is whether and to what extent an animal can feel pain and experience other forms of suffering. Do events that compromise health or interfere with natural behaviour generate the mental state of suffering? In this context, suffering can be defined as conscious experience (i.e. based on awareness of internal and external stimuli, Chandroo et al., 2004a) of something as very unpleasant (Dawkins, 1998). If non-human animals have no capacity for suffering, then arguably it does not matter that animals are exposed to such events (Bermond, 1997). A plant may be dying, but as it has no nervous system to generate mental experiences the possibility that it might be suffering does not arise. This question can arise for any group of animals, including invertebrates and larval fish, but we concentrate here on whether adult fish are capable of suffering and we approach this by considering the controversial issue of whether they experience physical damage as pain (Rose, 2002). To anticipate, our view and that of several other commentators (Chandroo et al., 2004a,b) is that adult fish probably do experience some of the adverse states that humans associate with pain and emotional distress, even if they do not have the capacity for self awareness necessary for conscious suffering 
in the full human sense (Braithwaite \& Huntingford, 2004). On this basis, if fish are injured or exposed to other harmful conditions, this is a cause for concern not just in terms of responsible stewardship of fish populations (Rose, 2002), but also in terms of the welfare of individuals.

People arguing on either side of this debate have used a number of kinds of evidence, none of them entirely satisfactory. Thus it has been argued that the longer the life span of a given species of animal and the more sophisticated its general behaviour, the greater its need for complex mental processes similar to those that in humans generate the conscious experience of suffering. In this context, therefore, it is relevant that the longest-living vertebrates are found among the fishes and that fish behaviour is rich, complicated and far from stereotyped. For example, we know that some species form mental representations of their environment and use these for quite complex feats of navigation (Reese, 1989; Rodriguez et al., 1994). Also, many fish live in social groups and some can recognise individual companions (e.g. Swaney et al., 2001). Fish can remember negative experiences. For example, paradise fish (Macropodus opercularis) avoid places where they have experienced a single attack by a predator and continue to do so for many months (Czanyi \& Doka, 1993) and carp (Cyprinus carpio) learn to avoid bait for up to three years after they have been hooked just once (Beukema, 1970). Several fish species are capable of learning complex spatial relationships and forming mental maps (Odling_Smee \& Braithwaite, 2003) using an homologous forebrain structure to that responsible for spatial memory in birds and mammals (Broglio et al., 2003); some are capable of forming hierarchical associations about order or sequence of spatial information (Burt de Perera, 2004). Furthermore, techniques used by experimental psychologists have demonstrated that different types of information, such as the timing of an event or the experience of a noxious stimulus, are processed in different areas of the forebrain, yet somehow these experiences can be integrated, and enable the fish to generate appropriate avoidance responses (Portavella et al., 2004; Yue et al., 2004). Thus, while animals could show these kinds of associative learning without necessarily having conscious awareness (Rose, 2002), clearly experiences such as exposure to a predator or tissue damage can be strongly aversive for a fish. And in fact, current literature on fish cognition indicates that several fish species are capable of learning and integrating multiple pieces of information that require more complex processes than associative learning (e.g. Braithwaite, 2006; Sovrano \& Bisazza, 2003). Thus, we conclude that where there is evidence of fish species with sophisticated cognitive and behavioural processes, the experience of suffering may be a real possibility.

On the specific point of whether fish experience physical injury as pain, it is helpful to consider current knowledge of pain perception pathways in mammals. In this context, the sensory structures that detect harmful (or noxious) stimuli are called nociceptors rather than pain receptors, to stress the fact that detecting and responding to noxious stimuli is not necessarily the same as feeling pain (Broom, 1998). What do we know of these systems in fishes? As far as the possession of receptors that detect harmful stimuli is 
concerned, more primitive fish such as lampreys (Petromyzon marinus) have free nerve endings in the skin that respond physiologically to mechanical pressure and heat, but behavioural reactions associated with nociception were not recorded (Matthews \& Wickelgren, 1978). It is also difficult to determine whether the mechanoreceptors in lamprey are truly nociceptive-specific or simply pressure-specific (Christenson et al., 1988). In at least one teleost fish (the rainbow trout, Oncorhynchus mykiss), however, anatomical and electrophysiological examination of the trigeminal nerve (which is known to convey pain information from the head and mouth in terrestrial vertebrates) has identified two types of nociceptor, A-delta and C fibres (Sneddon, 2002; Sneddon et al., 2003a).

In terms of the anatomy that generates the conscious experience of pain in humans, the brain of a fish is clearly far smaller relative to body size (some 300 times smaller by volume) and simpler in structure than that of a human (Kotrschal et al., 1998). In particular, the forebrain, or telencephalon, is relatively undeveloped compared with humans and fish lack cortical structures such as the neocortex, part of the brain with a key role in the subjective experience of pain in humans (Rose, 2002). However, there may be a greater degree of homology between the forebrain of fish and mammals (e.g. Broglio et al., 2003; Portavella et al., 2004) and even if this is not the case, we know that the same job can be done by different parts of the brain in different kinds of animals. For example, the brain of cephalopods is built on an entirely different plan from that of vertebrates, yet it generates highly complex behaviour (Hanlon \& Messenger, 1996). Likewise, visual stimuli are processed by part of the cerebral cortex in mammals, but in birds some visual information is processed extensively by the midbrain optic tectum (Shimizu \& Karten, 1993). It is not impossible that parts of the brain other than the cerebral cortex have evolved the capacity for generating negative emotional states/suffering in non-mammalian vertebrates.

Jawed fish are known to produce some of the natural opiates that modulate nociception in mammals (Substance P, enkephalins and $\square$-endorphins, Rodriguez et al., 1993; Zaccone et al., 1994; Balm \& Pottinger, 1995). This does not necessarily mean that these substances serve the same function in fish as they do in mammals, although the behavioural response of goldfish to analgesics is similar to that of a rat (Rattus norvegicus, Ehrensing et al., 1982). In mammals opiates act at neural levels below the neocortex (Rose, 2002), but this does not preclude their having a pain-suppressing effect. In support of this point, recent behavioural experiments have demonstrated effects of noxious stimulations around the mouth of rainbow trout (Sneddon et al., 2003a). In contrast to control treatments, fish administered with a weak acetic acid solution or bee venom showed dramatic and prolonged increases in opercular beat rate and suspension of feeding. In addition, the trout given the noxious stimulation were observed to rest on the substrate, rocking from side to side. Trout treated with acetic acid were also observed rubbing their snouts on the base and walls of the test tank. Similar studies have also shown that the adverse behaviour of fish under noxious 
Danish Centre for Bioethics and Risk Assessment

This is a post-print version of an article published in

Journal of Fish Biology by Wiley-Blackwell

For more articles on animal ethics, see www.animalethics.net

stimulation can be mitigated if an analgesic (morphine) is administered (Sneddon et al., 2003b). Taken together, these findings suggest that fish have the sense organs and the sensory processing systems required to perceive harmful stimuli and, probably, the central nervous systems necessary to experience at least some of the adverse states that we associate with pain in mammals. Hence our working position that adult fish have the capacity to perceive painful stimuli and that these are, at least, strongly aversive.

\section{Cost and benefits of human interactions with fishes}

Table 1 outlines a number of human activities that may potentially compromise the welfare of individual fish and so cause the harm against which any benefits must be weighed. The word "potentially" is used deliberately because at this point we wish to simply identify areas of possible concern. Harmful effects on welfare can be indirect, as when humans inadvertently alter natural habitats or expose fish to harmful chemicals, or direct, for example through commercial fisheries, through sports fisheries, through intensive production, through keeping fish as pets or in public aquaria or through scientific research. This review does not aim to make judgements about what is acceptable and what is unacceptable, but instead seeks to identify potentially harmful effects of human activities on fish welfare, as far as possible on the basis of documented evidence.

Table 1. Some human activities that could potentially compromise fish welfare

\begin{tabular}{ll}
\hline ACTIVITY & EXAMPLES OF POTENTIAL EFFECTS ON WELFARE \\
\hline Environmental & $\bullet$ Reduced availability of natural food. \\
Degradation & $\bullet$ Introduction of exotic species into existing fish communities. \\
& $\cdot$ Habitat modification, creating (e.g.) sub-optimal hydrological \\
& regimes. \\
& $\bullet$ Loss of or displacement from natural habitats. \\
& $\cdot$ Reduced population densities (or crowding) and abnormal social \\
& experiences. \\
& $\bullet$ Disturbance through tourism. \\
& Acute and chronic exposure to pollutants and litter. \\
\hline Commercial and & $\bullet$ Injury during trawling. \\
\hline
\end{tabular}


sports fisheries • Tagging/fin clipping during stock assessment.

- In both, tissue damage, physical exhaustion and severe oxygen deficit during capture.

- In both, pain and stress during slaughter.

- In angling, pain and stress in tethered fish when live bait is used.

- In angling, release of reared fish inappropriately equipped for survival in the wild.

- In angling, stocked fish introduced to lakes may be denied the opportunity to migrate.

Aquaculture - High densities in simple and constraining conditions, both in normal rearing conditions and for husbandry.

- Poor water quality.

- Aggressive interactions, which can cause damage and constrain access to food.

- Food deprivation (e.g. during disease treatment and before harvest).

- Handling and removal from water during routine husbandry procedures

- Unnatural light-dark regimes, to control breeding.

- Handling, constraint and, sometimes, low oxygen levels during transportation.

- Permanent adverse physical states and possibly increased levels of aggressiveness due to selection for fast growth.

- Increased exposure to predators, attracted to fish farms or used to grade out smaller fish (in extensive tilapia aquaculture).

- Transmission of disease between wild and farmed stocks. 
- Crowding, handling, removal from water and pain during slaughter.

\begin{tabular}{|c|c|}
\hline $\begin{array}{l}\text { Keeping } \\
\text { ornamental fish } \\
\text { and display }\end{array}$ & $\begin{array}{l}\text { - For ornamental fish, capture by sub-lethal poisoning. } \\
\text { - For ornamental fish, permanent adverse physical states due to } \\
\text { selective breeding. }\end{array}$ \\
\hline $\begin{array}{l}\text { fish in public } \\
\text { aquaria }\end{array}$ & $\begin{array}{l}\text { - For ornamental fish, release or escape of exotic species } \\
\text { - Inappropriate temperatures, poor water quality and physical } \\
\text { constraint during transport. } \\
\text { - Confined space and poor water quality once housed. } \\
\text { - Inappropriate physical conditions. } \\
\text { - Inappropriate social conditions, with shoaling fish at low densities } \\
\text { and predators with prey. } \\
\text { - Inappropriate diets. }\end{array}$ \\
\hline $\begin{array}{l}\text { Scientific } \\
\text { research }\end{array}$ & $\begin{array}{l}\text { - Genetic-modification induced for scientific research may have } \\
\text { detrimental effects on welfare. } \\
\text { - Fish used in the laboratory for experimental purposes are often } \\
\text { confined and may be exposed to a range of deliberately-imposed } \\
\text { adverse physical, physiological and behavioural states. } \\
\text { - Fisheries research often involves electrofishing, tagging, fin } \\
\text { clipping or otherwise marking fish, which potentially cause pain and } \\
\text { injury. } \\
\text { - And in both cases, handling during research procedures may cause } \\
\text { injury. }\end{array}$ \\
\hline
\end{tabular}


Having said that, it is worth stressing the benefits that humans derive from such activities. An estimated 150 million people worldwide rely on fisheries, aquaculture and associated activities for their livelihoods, with 38 million directly engaged in fishing, and 10 million in aquaculture as of 2002 (FAO 2004). Many of those engaged in fishing live in the world's poorest countries and remain landless - hence fisheries are the only means of support for whole communities. Aquaculture is making an increasing contribution as fisheries production from $3.9 \%$ of the total in 1970 to $31.9 \%$ in 2003 . This has been the result of increased aquaculture production against a backdrop of declining wild stocks. Between 1993 and 2003 there was an average annual increase of $9.4 \%$ in aquaculture production, with 42.3 million tonnes of aquatic animals produced in 2003 with an estimated farm-gate value of US\$61.0 billion (Lowther, 2005). Total world trade of fish and fisheries products was US\$58.2 billion (export value) in 2002 (FAO 2004) greater than that of rice, coffee, sugar and tea combined (World Bank 2005). The total value of fish exports worldwide was $\$ 58$ billion in 2002, greater than that of rice, coffee, sugar and tea combined (World Bank, 2005). Sports fisheries and ornamental fish keeping are major recreational activities. For example, in England and Wales there are an estimated 2.9 million freshwater anglers, equating to approximately $3.5 \%$ of the population. Of these, 2.3 million are coarse (non-salmonid) anglers making an average of 43 trips per year (National Rivers Authority, 1995). In 2001 there were 34.1 million anglers in the USA or approximately 1 in 6 of the population over 16 years of age, these people spent an estimated US\$34.6 billion on fishing, this is direct expenditure excluding employment and ancillary industries associated with fishing (U.S. Department of the Interior, Fish and Wildlife Service 2001). Ornamental fish are the third most common pet after dogs and cats, 35 to 40 million entering the US per annum, with a retail value of the fish and accessories ranged between 189 and 305 million US\$ (e.g. Mintel, 1991). Whether or not any of these activities do indeed harm fish is considered later, in Section 7.

\section{Natural threats to wild fish}

It is not self-evident that natural is necessarily good in any general sense. Additionally, in nature fish regularly make adaptive trade-offs between different needs. For example, like other animals they accept heavy costs in order to reproduce, in terms for example of physical injury and serious depletion of nutrient reserves/impairment of body condition; these are all conditions that we would regard as evidence of impaired welfare. This poses a problem when considering welfare, since what is natural conflicts with what is good in terms of physical condition, and there may be no real situation where all aspects of welfare are ideal. There is a moral difference between deviation from an optimal state that is caused by natural events and suffering caused by human activity (especially when fish have no choice of environment). Arguably, the term "welfare" is not relevant to adverse experiences that are not anthropogenic; even so, an understanding of the 
Danish Centre for Bioethics and Risk Assessment

This is a post-print version of an article published in

Journal of Fish Biology by Wiley-Blackwell

For more articles on animal ethics, see www.animalethics.net

natural threats encountered by wild fish and how frequently these occur (Table 2) can help to clarify our thoughts on fish welfare. Wild fish experience injury, poor environmental conditions and stressful events due to encounters with potential predators and fish of the same species, restricted food supplies, parasitic infection and disease and natural environmental change. One implication is that fish are likely to have mechanisms for dealing with the adverse conditions that they encounter naturally and that these will respond (up to certain limits) during their interactions with humans. Following from this, such natural responses might provide a means of assessing fish welfare.

Table 2. Natural threats to the welfare of wild fish

\begin{tabular}{ll}
\hline STRESSOR & COMMENT AND SELECTED EXAMPLES \\
\hline Predators & Predation rates can be very high. e.g. Excluding predators reduces \\
& mortality by $26 \%$ in wrasse (Shima, 2002). \\
& - Unsuccessful predatory attacks may cause wounding and an \\
& increased risk of disease. e.g. 30\% of wild sticklebacks \\
& (Gasterosteus aculeatus) showed injuries due to failed predatory \\
& attacks (Reimchen, 1994). \\
& - The threat of predation may suppress feeding and may cause fish to \\
& forage sub-optimally (Hart, 1997). \\
& - Many species live naturally in groups of the same species, which \\
& provide protection against predators. Obligate shoaling fish \\
& separated from companions will strive to join a shoal (Pitcher and \\
& Parrish, 1993). \\
& - In many other species (or in shoaling species under particular \\
& circumstances) conspecifics fight over resources and this can cause \\
& physical damage and depletion of energy reserves (Neat et al., \\
& 1998). Many mature wild Atlantic salmon parr have wounds from \\
& attacks by larger fish (Garcia de Leaniz, 1990). Losers may be \\
& deprived of resources and/or exposed to chronic social stress (Abbott \\
& \& Dill, 1989, Alanara, 1997). \\
\hline &
\end{tabular}




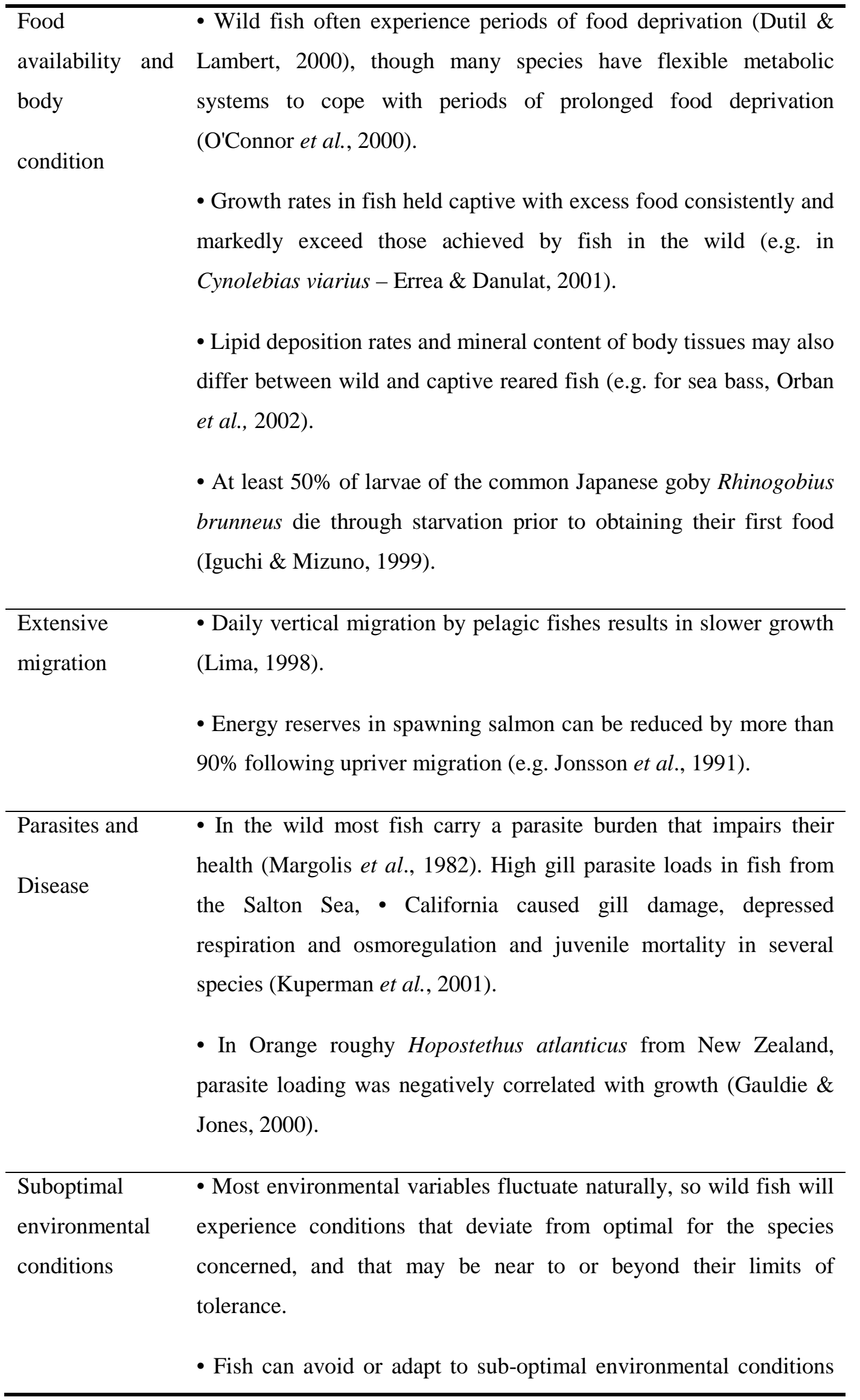


(at an energetic cost), but exposure to conditions beyond their limit

of tolerance is, by definition, lethal.

\section{How fish respond to natural threats to their welfare}

\section{Stress responses in fish}

Much of our understanding of how fish respond to adverse conditions comes from the extensive literature on the biology of stress. In common with all vertebrates, fish possess a suite of adaptive behavioural and physiological strategies that have evolved to cope with destabilising challenges, or stressors. Although there are some differences in detail arising from the contrast between the aquatic and terrestrial environment and from minor differences between the endocrine systems of fish and higher vertebrates, overall the stress responses of fish equate closely to those of other animals (Barton, 1997; Wendelaar Bonga, 1997). This parity extends to the behavioural elements of the stress response. Recent work with salmonid fish has shown that the integrated behavioural and physiological mechanisms that comprise the distinct "coping strategies" believed to be present in mammals (Koolhaas et al., 1999; Wingfield, 2003; Huntingford \& Adams, 2005) are also evident in fish, with heritable reactive and proactive traits demonstrated in rainbow trout (Øverli et al., 2005).

\section{Behavioural responses to stress}

Behavioural responses are an animal's first line of defence against adverse environmental change, predators, and social conflict, often being triggered by the same stimuli that initiate a physiological stress response. As noted above, it is becoming clear that in fish, as in other animals, individual's exhibit distinct behavioural strategies when faced with potentially threatening circumstances, and the type of behavioural response initiated, and the magnitude of the neuroendocrine response to the stressor, can be individual traits (Schjolden et al., 2005). The range of behavioural responses exhibited by fish to deal with stressors of varying magnitude is diverse. Altered patterns of swimming (changes in speed and direction) are shown in response to many stressors (e.g. Juell \& Fosseidengen, 2004). After an attack by another fish of the same species, fish may flee and hide or take up a submissive posture, often with altered body colour (e.g. O'Connor et al., 2000; Sutor \& Huntingford, 2003). When attacked by a predator, fish may respond by shoaling (Pitcher \& Parrish, 1993), freezing (e.g. Goodey \& Liley, 1985) or taking shelter (e.g. Brown \& Warburton, 1999) and may change colour in this context as well (Endler 1986). Feeding may be suppressed following an encounter with a predator, or inefficient feeding strategies may be adopted (Hart, 1993) and fish may avoid areas in which they have been attacked (Lima, 1998). Specific adaptive behaviour patterns are 
observed in response to parasitic disease (Furevik et al., 1993) and to tissue damage (for example, carp that are hooked in the mouth show rapid darting, spitting and shaking of the head (Verheijen \& Buwalda, 1988) and rainbow trout injected with acetic acid in their lips rub their snouts against the substratum (Sneddon $e t$ al., 2003).

\section{Acute physiological stress responses}

The neuroendocrine stress response in fish is virtually identical to that of mammals (Wendelaar Bonga, 1997) and is mediated by the hypothalamic-pituitary-interrenal (HPI) axis. Perception of a stressor by the fish initiates a rapid, neurally-stimulated release of catecholamines (adrenaline/epinephrine and noradrenaline/norepinephrine; Perry \& Bernier, 1999) from the chromaffin tissue, homologous to the mammalian adrenal medulla. This is accompanied by release of corticotropin-releasing hormone (CRH) from the hypothalamus which in turn promotes the release of corticotrophin (adrenocorticotrophic hormone, $\mathrm{ACTH}$ ) by the pituitary and subsequent synthesis and secretion of cortisol from by the interrenal tissue, the homologue of the mammalian adrenal cortex (Sumpter, 1997; Okawara et al., 1992; Weld et al. 1987). Cortisol concentrations return to pre-stress levels within hours of exposure to a brief stressor (Pickering \& Pottinger 1989; Waring et al., 1992), but elevated cortisol levels generally persist during continuous, chronic stress (Pottinger \& Moran, 1993; Pottinger et al., 1994). If a repeated stressor is not inherently damaging, acclimation, or habituation, can occur (Pickering \& Pottinger, 1985). The neuroendocrine stress response is responsible for coordinating and stimulating adaptive adjustments to respiratory and metabolic function and is endocrinologically more complex than indicated by this brief overview.

\section{Chronic physiological stress response}

Where fish cannot escape a stressor, or where the stressful stimulus is episodic or intermittent, prolonged activation of the stress response has deleterious consequences. These include loss of appetite, impaired growth and muscle wasting, immunosuppression and suppressed reproduction. Clearly, observing such changes provides strong indications that the well-being of the fish has been significantly compromised. Many of the adaptive elements of the acute response described above affect energy intake and increase energy utilisation, so prolonged activation of the HPI axis is likely to reduce growth indirectly through a negative effect on energy balance. In addition, secretion of growth hormone is reduced in fish during periods of stress (Pickering et al., 1991; Farbridge \& Leatherland, 1992), so there are also direct effects on the mechanisms that control growth. Poor growth has also been reported in wild fish as a result of environmental stressors such as altered pH (e.g. Puste \& Das, 2001), reduced dissolved oxygen (Kramer, 1987) and salinity (Brett, 1979). Since growth and reproduction are functionally linked (Thorpe et al., 1998), 
stress-induced impairment of growth may indirectly interfere with maturation. Additionally, reproductive activity is suppressed directly during periods of stress, via a wide range of mechanisms (Pottinger, 1999).

In teleost fish, defence against disease is mainly based on a non-specific immune system that does not depend on prior disease challenge. The main components are chemicals in the body fluids that destroy or inactivate invading organisms and circulating and tissue-dwelling phagocytes that engulf or destroy invading organisms. The specific immune system, which has a memory component that can adapt to different invading organisms (e.g. Press, 1998) is less well developed than in birds and mammals, comprising circulating lymphocytes responsible for antibody production and phagocytic cells, which have an additional role in presenting antigens to the specific immune system. Chronic stress has a generally immunosuppressive effect in fish, mediated in particular by the actions of cortisol (Weyts et al., 1999), and increased mortality due to fungal and bacterial pathogens (e.g. Pickering \& Pottinger, 1989; Plumb, 1994) is the common outcome.

\section{Functional considerations}

The stress response has evolved to assist the survival of the animal under demanding conditions in the natural environment. However, natural stressors tend to be brief and/or avoidable. In contrast those stressors that are imposed upon fish by anthropogenic agents may be unavoidable and prolonged or repetitive. Under such circumstances, chronic or repeated activation of behavioural and physiological stress responses is maladaptive and potentially harmful. Ideally, indicators of welfare should signal problems in advance and allow intervention before this state has been reached.

\section{Assessing fish welfare}

\section{Ways of measuring fish welfare.}

Based on knowledge of the natural responses of fish to adverse conditions, the physiological, health and/or behavioural status of individual fish have been used as indicators of compromised welfare, though the link between components of the stress response and welfare is not simple.

Stress responses represent an animal's natural reaction to challenging conditions and these are often used as indicators of impaired welfare, so studies of physiological stress feature prominently in welfare research. However, it is important to recognise that physiological stress is not synonymous with suffering (Dawkins, 1998). There is no particular reason to suggest that the temporary physiological activation that prepares fish for activity is detrimental to welfare and in some contexts short-term stress responses (for example, in 
anticipation of feeding) may well be beneficial (Moberg, 1999). Indirect effects such as suppressed reproduction may well be adaptive responses to poor conditions in the wild, but even so it seems reasonable to assume that in captive fish they indicate exposure to chronic, unavoidable stress, which may have compromised welfare. Thus although the concept of stress does not fully capture the complexities of animal welfare, monitoring stress responses may give us an important part of the picture. In particular, where several components of the stress response (including up-regulation of particular genes, Ribas et al., 2004) are all influenced in a similar way by the same condition, this suggests that there is cause for concern about the welfare of the fish involved.

The link between health and welfare is also complex. If an individual fish shows disease symptoms, it seems reasonable to infer that it is in a poor state of welfare, as a direct result of the disease. However, the converse is not necessarily true since the welfare of a healthy fish may be compromised, for example through inappropriate social environments. In addition, because stress can suppress immune function and increase risk of infection, a high incidence of disease and mortality in a population may indicate that there is an underlying problem with the fish's environment. It would be overly simplistic to assume that disease is invariably the result of poor living conditions or that the occurrence of disease inevitably implies that the problem is due to human mismanagement. Even fish experiencing optimal conditions may suffer from disease and serious epidemics occur in populations of wild fish (e.g. Epizootic Ulcerative Syndrome, Lillie \& Roberts, 1997).

Behavioural studies have been important in welfare research for a number of reasons. Since altered behaviour is an early and easily observed response to adverse conditions, specific responses to natural stressors (such as 'freezing' in the presence of a predator or rubbing to remove ectoparasites) can be used as an indicator of impaired welfare. Likewise, since animals pay attention to those stimuli that are currently important for fitness, changes in attentional state can be used to highlight welfare problems. For example, trout exhibit strong avoidance responses when exposed to a novel object (Sundstrom et al., 2004). Such responses are suppressed if the fish has been exposed to a noxious stimulus, but not in fish treated with some form of analgesic. The fact that exposure to noxious stimuli interferes with the normal neophobic responses suggests that fish give a high priority to such stimuli (Sneddon et al., 2003b). Additionally, since animals may suffer if prevented from performing their full behavioural repertoire, behavioural deficits have been used to identify conditions that compromise welfare (Mench \& Mason, 1997). Behavioural techniques such as choice tests that give insights into the priorities that animals place on different options have proved valuable in welfare research on birds and mammals, even though the underlying assumption that animals choose what is good for them is not always valid (Dawkins 1998, 2004). Choice tests have often been used on fish, though the aim is not usually related to fish welfare; for example, fish may be required to chose 
between different temperatures (Bevelhimer, 1996), between schools of different composition (Metcalfe \& Thomson, 1995) or between water with different concentrations of potentially lethal pollutants (Giattina \& Garton, 1983). There is clearly scope for more work along these lines directly aimed at identifying conditions that promote good welfare in fish.

\section{Integrating different measures of welfare}

Because there are so many potential signs of impaired welfare, the most reliable assessment of well-being will be obtained by examining a range of informative measures. This raises the question of how such a battery of measures can be combined objectively to give an overall impression of welfare, and there are various methods of multivariate analysis that might be used in this context. For example, Principal Components Analysis was used to integrate four commonly used measures of fish welfare reflecting different functional systems (condition of body and fins and plasma concentrations of glucose and cortisol) into a single welfare score for farmed Atlantic salmon (Turnbull et al., 2004). As well as reflecting coherence within the data, this score was consistent with the evaluation of welfare by experienced farmers and was significantly negatively related to, among other things, stocking density and cage position. In a related study using experimental tanks, a similar multivariate score was used to relate welfare to disturbance (among other factors), welfare being best in more frequently disturbed tanks. Behavioural studies suggested that this counter-intuitive result arose because aggression during feeding was suppressed by human disturbance (Adams et al., in prep.).

\section{Sensitive and easily applied welfare indicators for fish}

Data on fish physiology, biochemistry and behaviour are informative, but collecting them is time consuming, technically complex and involves handling or killing fish in order to collect blood or other tissue. Noninvasive methods exist, such as measuring cortisol levels in the water in which fish have lived (Ellis et al., 2004) or in their faeces (Oliveira et al., 1999, Turner et al., 2003), but these sometimes lack the precision of direct measurements made on individual fish. Such intensive work is necessary in scientific research, but is impractical for everyday use, in pet shops or on working fish farms, for example. What is needed for practical management of welfare here is a set of simple, non-intrusive signs or danger signals that can be used easily without complicated laboratory analysis. A number of possible welfare indicators can and have been used to assess the welfare of individual fish (Table 3). Some of these are based on assessments of health that can be used on dead fish (see Tierney \& Farrell, 2004), but others are based on behaviour and production. These are well known to people with a practical interest in fish welfare, such as owners of ornamental fish and responsible fish farm workers, as the study by Turnbull et al. (2004) cited above showed. 
How well these signs work in any given case will depend on the species concerned (for example, eye colour may be a good indicator of social stress in salmon, but not in sticklebacks), on circumstances (for example, depleted energy reserves might be cause for concern in an immature salmon, but not in one that has just bred) and also on individual status (failure to feed may be a sign of poor welfare in a juvenile salmon in the summer, but not necessarily in the winter when they may show adaptive natural anorexia). The potential for using the full range of available indicators will vary with the context in which fish welfare is to be assessed; fish farmers may have to rely on a few signs, but people keeping ornamental fish are well placed to use many of them, on all their fish. In addition, on farms, sick or damaged fish may be more conspicuous than those in good condition, so it is important to develop sampling protocols that give an accurate picture of the welfare status of the whole population.

\section{How human activities affect fish welfare}

The scientific study of fish welfare lags behind that of the welfare of other vertebrates (reflecting the pressure of public concern), but there is still an extensive literature on the subject, using several of the welfare indicators outlined above. It is beyond the scope of this review to provide an exhaustive account of this literature, but in this section we comment briefly on the subject, using just a few examples and concentrating on the areas of potential concern identified in Table 1.

Table 3. Possible easily-measured indices of welfare and examples of their use. We list only those based on direct observations of fish rather than the systems in which they are held.

\begin{tabular}{|c|c|}
\hline $\begin{array}{l}\text { POSSIBLE } \\
\text { INDEX }\end{array}$ & EXAMPLES \\
\hline $\begin{array}{l}\text { Changes } \\
\text { colour }\end{array}$ & $\begin{array}{l}\text { Stress-induced changes in skin or eye colour (which have a complex } \\
\text { neural and hormonal background) have been reported in a number of } \\
\text { fish species, including ornamental species (Etscheidt \& Manz, 1992) } \\
\text { and so could be a sign of exposure to adverse events. E.g. eye colour } \\
\text { as an index of social stress/subordinate status in salmonids } \\
\text { (O'Connor et al. 2000; Sutor \& Huntingford, 2003). }\end{array}$ \\
\hline $\begin{array}{l}\text { Changes in } \\
\text { ventilation rate: }\end{array}$ & $\begin{array}{l}\text { A high oxygen demand is reflected by rapid irrigation of the gills. } \\
\text { The rate of opercular beats is therefore increased by stress and can } \\
\text { be counted automatically or by eye. This, together with a visual }\end{array}$ \\
\hline
\end{tabular}


assessment of gill status, is used as a sign of incipient problems in ornamental fish (Etscheidt \& Manz, 1992) and ventilation rate has been used to monitor exposure to pollutants (Handy \& Depledge, 1999).

\begin{tabular}{|c|c|}
\hline $\begin{array}{l}\text { Changes in } \\
\text { swimming and } \\
\text { other behaviour } \\
\text { patterns }\end{array}$ & $\begin{array}{l}\text { Fish may respond to unfavourable conditions by changing swimming } \\
\text { speed and space use (Morton, 1990; Etscheidt \& Manz, 1992; } \\
\text { Kristiansen et al., 2004). Abnormal swimming has been used as a } \\
\text { sign of poor welfare in farmed fish (Holm et al., 1998). Behavioural } \\
\text { responses to adverse conditions (or lack of responsiveness to specific } \\
\text { stimuli) are signs of both general and specific trouble (Morton, } \\
\text { 1990). These include excessive activity or immobility (Etscheidt \& } \\
\text { Manz, 1992), body positions that protect injured fins, escape } \\
\text { attempts and rubbing to dislodge ectoparasites (Furevik et al., } \\
\text { 1993). }\end{array}$ \\
\hline
\end{tabular}

Reduced food There are many reasons why a fish might not eat, but the fact that intake feeding is suppressed by acute and chronic stress means that an unexpected loss of appetite is a sign of potentially impaired welfare.

Loss of Fish change shape and/or lose weight for many reasons, but because condition reduced feeding and mobilisation of reserves are secondary stress responses, where fish are regularly weighed and measured, or where body shape can be assessed by eye (for example by the visibility of the vertebrae, Escheidt \& Manz, 1992) loss of condition can indicate possibly impaired welfare.

\begin{tabular}{ll}
\hline Slow growth & Growth rates in fish are flexible and naturally variable, but provided \\
& we have an estimate of expected growth prolonged low rates of \\
& growth may be indicative of chronic stress. Thus where fish are \\
& regularly weighed or where size can be assessed by eye (or by \\
& underwater camera) slow growth can be used as a possible sign of \\
& trouble. \\
\hline Morphological & Because adverse conditions can interfere with normal development, \\
abnormalities & the occurrence of morphological abnormalities can be used as an \\
& indicator of poor larval rearing conditions (Boglione et al., 2001; \\
& Cahu et al., 2003), although whether this represents problem for \\
& welfare depends on the degree of sentience of the larvae concerned.
\end{tabular}


Injury, including damage
Injury may be a direct consequence of an adverse event, in which

fin case, a high frequency of such injuries is a sign of poor welfare. For example, dorsal fin injury in salmonids is often caused by attacks from conspecifics (Turnbull et al., 1998) and scales that are dislodged with blood visible rather than lying flat, are a sign of poor welfare in ornamental fish (Etscheidt \& Manz, 1992). In addition, because immune responses can be suppressed by cortisol, slow recovery from injury (or a high incidence of injury) may be a sign of generally poor conditions. As well as acute damage, healed injuries may result in long-term abnormalities (e.g. in salmon healed fin injuries may cause permanently short fins) that potentially compromise performance and welfare.

Disease states Since the causes of most aquatic diseases are complex and dependent on environmental conditions, the presence of disease can indicate an underlying problem with the environment or management. Increased incidence of disease in any population of fish should be treated as a warning that there may be other underlying problems. However, interpreting the welfare implications of an observed disease requires a detailed understanding of the natural history of the disease. In some cases, diseases are not sufficiently well understood to interpret their implications for welfare. Even records of treatment can be difficult to interpret since they may either indicate that the owner is responding appropriately to disease outbreaks or the fish are being exposed to a predictable endemic disease.

Reduced For many farmed species, reproduction is prevented or avoided in reproductive growing stock. Where this is not the case, for example, in brood performance: stock or in ornamental fish, because chronic stress impairs reproductive function, failure of adult fish to breed or to display normal patterns of reproductive development when feed, light and temperature regimes are appropriate is a possible sign of poor welfare. 


\section{Environmental degradation}

As far as environmental degradation is concerned, this is clearly a cause of poor welfare in very large numbers of fish (Montgomery \& Needleman, 1997). Heavy metals cause extensive gill damage in acidic water, but are non-toxic in hard, alkaline water. (see Wedermeyer, 1997). We now know that heavy tourism can cause detectable stress response of reef fish (Oliveira et al., 1999). Pollution of water bodies as a result of direct or indirect input of industrial emissions and effluents is widespread through natural fish habitats and can severely affect fish welfare. To give just a few examples, reduced growth rates in fish has been reported in response to low pH (Puste \& Das, 2001) and reduced dissolved oxygen (Kramer, 1987). Eutrophication can impair growth of fish even when food is available in excess, but at the same time remedial measures to reduce impacts of human activities may also have adverse effects on fish. For example, following policyinduced reductions in phosphorus input and subsequent 'oligotrophication' of the waters, growth rates were reduced in largemouth bass in a well established fishery, due to reduced primary productivity with consequences further up the food chain (Maceina \& Bayne, 2001).

\section{Commercial and sports fisheries}

The welfare of fish caught by commercial fisheries (still the largest area of human-fish interactions) is also a cause for serious concern. Fish are harmed by capture (e.g. cortisol levels increase in sea bream captured by trammel net and many fish are mortally injured, Chopin \& Arimoto, 1995) and slaughter methods (especially asphyxia) are highly stressful (Poli et al., 2002). In addition, non-target species captured as by-catch are often injured or killed (Pronovi et al., 2001). A growing scientific literature has shown that several aspects of sports fisheries have negative effects on fish welfare; some of these studies are shown in Table 4. Compared to aquaculture very few studies have addressed fish welfare in commercial fisheries.

Table 4. Examples of scientific studies of the impact of various aspects of angling on fish welfare.

\begin{tabular}{|c|c|}
\hline PRACTICE & SOME DEMONSTRATED EFFECTS ON WELFARE \\
\hline $\begin{array}{l}\text { Capture } \\
\text { hooking }\end{array}$ & $\begin{array}{l}\text { Injury and mortality following hooking is common, but primarily } \\
\text { associated with deep-hooked fish (DuBois et al., 1994; Hulbert \& } \\
\text { Engstrom-Heg, 198; Muonehke \& Childress, 1994). }\end{array}$ \\
\hline $\begin{array}{l}\text { Capture - } \\
\text { playing / landing }\end{array}$ & $\begin{array}{l}\text { Capture of fish of various species by rod and line elicits a stress } \\
\text { response of short duration (Gustaveson et al., 1991; Pankhurst \& } \\
\text { Dedual, 1994; Pottinger, 1998). Estradiol levels are suppressed in } \\
\text { rainbow trout within } 24 \text { h of capture by rod and line (Pankhurst \& }\end{array}$ \\
\hline
\end{tabular}


Danish Centre for Bioethics and Risk Assessment

This is a post-print version of an article published in

Journal of Fish Biology by Wiley-Blackwell

For more articles on animal ethics, see www.animalethics.net

\begin{tabular}{|c|c|c|}
\hline & & $\begin{array}{l}\text { Dedual, 1994). Capture and playing in largemouth bass } \\
\text { (Micropterus salmoides) produces marked increases in heart rate } \\
\text { (Cooke } \text { et al., 2004). }\end{array}$ \\
\hline $\begin{array}{l}\text { Capture } \\
\text { handling }\end{array}$ & - & $\begin{array}{l}\text { Exposure of exercised fish to air can have severe metabolic effects } \\
\text { (lactate increase and altered acid-base balance) that may be greater } \\
\text { in larger fish (Ferguson et al., 1993). Capture and handling } \\
\text { suppresses reproductive function in brown trout (Melotti et al., } \\
\text { 1992). }\end{array}$ \\
\hline $\begin{array}{l}\text { Retention } \\
\text { constraint } \\
\text { release }\end{array}$ & I & $\begin{array}{l}\text { Retention of fish post-capture in either keep nets or stringers induces } \\
\text { physiological stress responses, but recovery following release can } \\
\text { be rapid (Pottinger, 1998; Sobchuk \& Dawson, 1988). Hooking and } \\
\text { handling for release can increase scale damage by } 16 \% \text { (Broadhurst } \\
\& \text { Barker, 2000), possibly making released fish liable to infection. } \\
\text { Behavioural modification can occur following release (Mesa \& } \\
\text { Schreck, 1988; Olla \& Davis, 1989; Cooke \& Phillip, 2004)). } \\
\text { Livewell confinement increased mortality in walleye and largemouth } \\
\text { bass used in live release tournaments (Suski et al., 2005). }\end{array}$ \\
\hline
\end{tabular}

\section{Aquaculture}

Because there is growing public concern for well-being farmed fish, there has been a considerable amount of research into the impact of many aspects aquaculture practice on fish welfare, some of which is reviewed by Conte (2004). More examples are given in Table 5.

Table 5. Examples of scientific studies of the impact of various aspects of aquaculture on fish welfare.

\begin{tabular}{ll}
\hline PRACTICE & SOME DEMONSTRATED EFFECTS ON WELFARE \\
\hline Transportation & Transportation induces physiological stress requiring prolonged \\
& recovery (Bandeen \& Leatherland, 1997; Barton, 2000; Rouger et \\
& al., 1998; Iversen et al., 1998; Sandodden et al., 2001; Chandroo et \\
& al.,. 2005).
\end{tabular}




\begin{tabular}{|c|c|}
\hline Handling and & $\begin{array}{l}\text { Physical disturbance evokes a neuroendocrine stress response in } \\
\text { many species of farmed fish (reviewed by Pickering 1998) and } \\
\text { reduces disease resistance (Stangeland et al., 1996). Handling stress } \\
\text { increases vulnerability to whitespot in channel catfish (Davis et al., } \\
2002 \text {. }\end{array}$ \\
\hline $\begin{array}{l}\text { Confinement } \\
\text { and } \\
\text { short-term } \\
\text { crowding }\end{array}$ & $\begin{array}{l}\text { Physical confinement in otherwise favourable conditions increases } \\
\text { cortisol and glucose levels and alters immunological activity in } \\
\text { various species (Garci-Garbi, 1998). Carp (Cyprinus carpio) show a } \\
\text { mild, physiological stress response to crowding that declined as the } \\
\text { fish adapted, but crowded fish are more sensitive to an additional } \\
\text { acute stressor (confinement in a net; Ruane et al., 2002). Crowding } \\
\text { during grading increases cortisol levels for up to 48h in Greenback } \\
\text { flounder Rhombosolea tapirinia, Gunther (Barnett \& Pankhurst, } \\
\text { 1998). }\end{array}$ \\
\hline $\begin{array}{l}\text { Inappropriate } \\
\text { densities }\end{array}$ & $\begin{array}{l}\text { High densities may impair welfare in some species (trout and } \\
\text { salmon: Ewing \& Ewing 1995, sea bass, Dicentrarchus labrax L, } \\
\text { Vazzana, 2002, red porgy, Pagrus pagrus, Rotllant \& Tort, 1997, } \\
\text { seabream Sparus auratus, Montero et al., 1999), but enhance it in } \\
\text { others (Arctic charr Jergensen et al., 1993). Halibut suffer less injury } \\
\text { at high densities (Greaves, 2001) but show more abnormal } \\
\text { swimming (Kristiansen \& Juell, 2002; Kristiansen et al., 2004). The } \\
\text { relationship may not be linear (in salmon negative effects begin to } \\
\text { kick in at a critical density, Turnbull et al., 2004) and density } \\
\text { interacts with other factors such as water quality (Ewing \& Ewing, } \\
\text { 1995; Scott et al., 2001;, Ellis et al., 2002). Genes coding for heat } \\
\text { shock proteins are over-expressed in sea bass held at high densities } \\
\text { (Gornati et al., 2004). An enolase gene is up-regulated in sea bream } \\
\text { held at high densities (Ribas et al., 2004). }\end{array}$ \\
\hline $\begin{array}{l}\text { Enforced social } \\
\text { contact }\end{array}$ & $\begin{array}{l}\text { Aggression can cause injury in farmed fish, especially when } \\
\text { competition for food is strong (Greaves \& Tuene, 2001). } \\
\text { Subordinate fish can be prevented from feeding (Cubitt, 2002), grow } \\
\text { poorly and are more vulnerable to disease (reviewed by } \\
\text { Wedermeyer, 1997). }\end{array}$ \\
\hline
\end{tabular}


Water quality Many adverse effects of poor water quality have been described, deterioration with different variables interacting. E.g. undisturbed salmonids use c $300 \mathrm{mg}$ of oxygen per $\mathrm{kg}$ of fish per hour and this can double if the fish are disturbed. For these species, access to aerated water is essential for health (Wedermeyer, 1997). Immunoglobulin levels fall in sea bass held at low oxygen levels (Scapigliati et al., 1999). Poor water quality mediates density effects on welfare in rainbow trout (Ellis et al., 2002).

\begin{tabular}{|c|c|}
\hline $\begin{array}{l}\text { Bright light } \\
\text { and } \\
\text { photoperiod } \\
\text { manipulation }\end{array}$ & $\begin{array}{l}\text { Atlantic salmon avoid bright light at the water surface, except when } \\
\text { feeding (Fernö et al.,1995; Juell et al., 2003). Continuous light is } \\
\text { associated with increased growth in several species (e.g. cod: } \\
\text { Puvanendran \& Brown, 2002) }\end{array}$ \\
\hline $\begin{array}{l}\text { Food } \\
\text { deprivation }\end{array}$ & $\begin{array}{l}\text { Dorsal fin erosion increases during periods of fasting in steelhead } \\
\text { trout (Winfree et al., 1998). Plasma glucose increased in Atlantic } \\
\text { salmon after } 7 \text { days without food, but other welfare indices were } \\
\text { unaffected (Bell, 2002). Atlantic salmon deprived of food for longer } \\
\text { periods (up to } 86 \text { days) lost weight and condition, but this stabilised } \\
\text { after } 30 \text { days (Einen et al., 1998). Farmed Atlantic salmon swim } \\
\text { slower and fight less during feeding bouts when fed on demand } \\
\text { (Andrews et al., 2002). }\end{array}$ \\
\hline $\begin{array}{l}\text { Disease } \\
\text { treatment }\end{array}$ & $\begin{array}{l}\text { Therapeutic treatments themselves may be stressful to fish (e.g. } \\
\text { Griffin et al., 1999, 2002; Thorburn et al., 2001; Yildiz \& Pulatsu, } \\
\text { 1999; Sorum \& Damsgard, 2003). }\end{array}$ \\
\hline $\begin{array}{l}\text { Unavoidable } \\
\text { contact } \\
\text { with predators }\end{array}$ & $\begin{array}{l}\text { Brief exposure to a predator causes increased cortisol levels and } \\
\text { ventilation rate and suppressed feeding (e.g. Metcalfe et al., 1987). } \\
\text { Mortality and injury due to attacks by birds and seals can be high } \\
\text { among farmed fish (e.g. Carss, 1993). }\end{array}$ \\
\hline Slaughter & $\begin{array}{l}\text { All slaughter methods are stressful, but some are lees so than others } \\
\text { (Robb et al., 2000; Southgate \& Wall, 2001). Sea bass killed by } \\
\text { chilling in ice water had lower plasma glucose and lactate levels and } \\
\text { showed less marked behavioural responses than those killed by other } \\
\text { methods, in particular by asphysia in air and electro-stunning (Poli } \\
\text { et al., 2002; Skjervold et al., 2001), see Robb \& Kestin, 2002; Lines }\end{array}$ \\
\hline
\end{tabular}




\section{Keeping ornamental fish}

Various bodies are concerned with ethical issues arising from the keeping of ornamental fish, whether in private homes or in public aquaria. These issues include conservation of species used by the aquarium trade and their habitats as well as the welfare of the individual fish themselves. Table 6 gives examples of some recent scientific of the impact of various practices in ornamental fish keeping on the welfare of individual fish.

Table 6. Examples of scientific studies of the impact of various aspects of ornamental fish keeping on fish welfare.

\begin{tabular}{|c|c|}
\hline $\mathbf{P R}$ & ED EFFECTS \\
\hline $\begin{array}{l}\text { Capture by } \\
\text { sublethal poisons }\end{array}$ & $\begin{array}{l}\text { Marine tropical fish captured by sodium cyanide suffer very high } \\
\text { mortality for several weeks after capture (Hignette, 1984). Clove } \\
\text { oil is a better alternative (Erdmann, 2002). }\end{array}$ \\
\hline Tra & $\begin{array}{l}\text { Mortality during capture of ornamental fish from South America } \\
\text { ranges may be as high as } 30 \% \text {. A further } 5 \text { to } 10 \% \text { mortality is } \\
\text { estimated to occur during transportation and at the holding facilities } \\
\text { (Ferraz de Olivera, 1995). During the acclimation period following } \\
\text { importation mortalities can be up to } 30 \% \text { (FitzGibbon, 1993). } \\
\text { Shipping of zebra fish (Brachydanio rerio) by road in oxygenated } \\
\text { bags elevated cortisol levels, but recovery is rapid on transfer to } \\
\text { aquaria (Pottinger \& Calder, 1992). }\end{array}$ \\
\hline
\end{tabular}

Constraint in a See above, under aquaculture.

confined space

\begin{tabular}{ll}
\hline Handling & See above, under aquaculture. \\
\hline $\begin{array}{l}\text { Inappropriate } \\
\text { densities/species }\end{array}$ & $\begin{array}{l}\text { Lack of appropriate social environment (wrong species or } \\
\text { inampropriate numbers) is an important cause of poor health in } \\
\text { ombinations }\end{array}$ \\
\hline ooor water & $81 \%$ of ornamental fish are held outside the optimal pH range, 36\% \\
quality & at inappropriate temperatures (Etscheidt \& Manz, 1992). Poor \\
& water quality is the commonest cause of mortality in ornamental \\
\hline
\end{tabular}




\begin{tabular}{|c|c|}
\hline $\begin{array}{l}\text { Deprivation of } \\
\text { social contact }\end{array}$ & $\begin{array}{l}\text { Angelfish transferred singly to a new tank take longer to resume } \\
\text { feeding than those transferred in groups of } 3 \text { or } 5 \text { (Gomez-Laplaza } \\
\& \text { Morgan, 1993). }\end{array}$ \\
\hline $\begin{array}{l}\text { Inappropriate } \\
\text { food levels }\end{array}$ & $\begin{array}{l}\text { Inappropriate range and types of food can cause poor health in } \\
\text { ornamental fish (Etscheidt, 1995). Inappropriate feeding is not } \\
\text { usually a direct cause of mortality in ornamental fish, but can be a } \\
\text { contributory factor (Schunck, 1980). }\end{array}$ \\
\hline $\begin{array}{l}\text { Unavoidable } \\
\text { contact with } \\
\text { predators }\end{array}$ & $\begin{array}{l}\text { In } 19 \% \text { ornamental tanks prey were housed in small tanks in direct } \\
\text { contact with predators (Escheidt \& Manz, 1992; Foggitt, 1997). See } \\
\text { above under aquaculture. }\end{array}$ \\
\hline Disease treatment & re. \\
\hline
\end{tabular}

\section{Scientific research}

Scientific research (including research by welfare scientists) raises various concerns about its impact on welfare of its subjects, which have been the subject of a number of reviews and guidelines (Nickum, 1988; Borski \& Hodson, 2003; Jackson, 2003). Such research (including studies of fish) is strongly regulated in many countries to ensure that harm in terms of compromised welfare is outweighed by benefits in terms of enhanced knowledge on important issues (e.g., the UK Animals (Scientific Procedures) Act, 1986), and is not considered further in this review.

\section{What are the welfare issues?}

A number of general points emerge from the brief literature review presented in the previous section:

1. Some categories of human activity do indeed compromise fish welfare: If one accepts disturbed behaviour, chronically elevated cortisol levels, increased incidence of disease and poor growth (for example) as indicators of welfare in fish, then there are many examples of harmful effects of human activities on fish welfare (Table 2).

2. The same factor can have variable effects on fish welfare depending on circumstances: Experiments in which the same environmental factor (for example, stocking density) is manipulated often give variable results because different species of fish, and different life history stages of the same species, require different environments for good welfare. Additionally, even within the same species and age group, inherited individual differences in strength of response to a standardised stressor have been reported, for example in 
rainbow trout (Pottinger \& Carrick, 1999) and in carp (Cyprinus carpio L, Tanck et al., 2001). Finally, the complex nature of fish welfare means that the various factors that impact on it may interact. For example, in aquaculture a given stocking density may generate signs of poor welfare under one flow regime (Ellis et al., 2002) or level of disturbance (Turnbull et al., 2004), but not under other conditions.

3. It is therefore not possible to specify conditions that guarantee fish welfare: The fact that the effect of varying one factor (such as density) frequently depends on the status of many other factors (such as disturbance and water quality), leads to the important conclusion that, even for a particular species, gender and age of fish, we cannot guarantee the welfare by defining a simple set of husbandry conditions. This in turn emphasises the need for sensitive on-the-spot indicators of welfare, as discussed in section 6.3.

4. Fish are different from other vertebrates in ways that have important implications for welfare: The effects of human activity on fish welfare are not always what one would predict by extrapolating from birds and mammals. One way to emphasise this point is to consider the influential framework for animal welfare based on the so-called five freedoms (used by the UK Farm Animal Welfare Council) or domains in which welfare may be compromised (Mellor \& Stafford, 2001) and how this framework might be applied to fish.

Domain 1. Water and food deprivation, malnutrition. Animals should have ready access to clean water and an appropriate diet in sufficient quantities and with a composition that maintains full health and vigour.

Fish allow their body temperature to fluctuate with that of the environment (i.e. they are ectothermic) and also show striking natural variation in appetite and the evidence suggests that food deprivation is not such a critical aspect of their welfare. Wild fish show marked changes in appetite (some temperature-based and others depending on life history events) that determine the effect of food deprivation on welfare. In the winter juvenile salmon may become naturally anorexic, eating little for weeks (Metcalfe \& Huntingford, 1988). These fish will feed when their energy reserves fall to a critical level, but up to this point, low rations would not compromise welfare. On the other hand, maturing salmon show a spontaneous peak in appetite in spring, when nutrient reserves for migration and spawning are accumulated (Kadri et al., 1996) and food deprivation at this point may well compromise welfare. This is not to say that it is acceptable to starve fish for long periods; they certainly have mechanisms that motivate them to feed when their stomachs are empty and their nutritional reserves are low and restricted food may have other effects such as increasing levels of aggression. However, under appropriate circumstances periods of food deprivation may not cause welfare problems and may well mitigate adverse effects of other husbandry activities. The natural diet of wild fish varies markedly between species and as with other vertebrate groups, it is important to ensure that captive fish are given a nutritionally appropriate diet, although in most species we do not know exactly what this should be. The nutritional requirements of established farmed species are well known, the industry has invested substantially in developing appropriate diets and farmed fish no doubt enjoy better nutrition than their wild counterparts. However, for less well established species, there may be nutritional problems. For example, diets lacking in critical micronutrients impair welfare in many species, according to a range of 
indicators such as high mortality, morphological abnormalities, poor immune function, abnormal behaviour, poor feeding, impaired sensory function and slow growth (De Silva \& Anderson, 1995). As far as water deprivation is concerned, juvenile salmon transferred to seawater too soon in the smolting process can become severely dehydrated, and may die as a consequence (Southgate \& Wall, 2001).

Domain 2. Environmental challenge. Animals should have a suitable environment, including shelter and a resting area, whether outdoors or indoors.

Since fish are in intimate contact with their environment through the huge surface of their gills, water quality (in terms of dissolved oxygen, ammonia and $\mathrm{pH}$ ) and the presence of contaminants (organic and inorganic pollutants) are probably the most critical aspects of the environment for fish welfare and also the best defined. Optimal conditions vary markedly between species. For example, cyprinid fish are very tolerant of low dissolved oxygen levels whereas salmonid fish are not (Wedemeyer, 1996). Within the cichlids, some species are found naturally in waters with a $\mathrm{pH}$ as low as 4 , whereas others flourish at $\mathrm{pH}$ as high as 9 (Lowe-McConnell, 1991; Ross, 2000). The flow characteristics of the fish's natural habitat are also of importance, some species preferring static water, others tolerating or preferring relatively high flow rates. The extent to which the nature of the substratum is important for welfare, particularly in bottom-dwelling species, is not known, but several species have been shown to grow better when shelters are available (e.g. Gwak, 2003). In general, except for the high densities involved, the environment experienced by farmed fish is markedly less complex than that experienced by their wild counterparts. Several behavioural deficits in hatchery-reared fish (for example, inability to handle live prey and impaired anti-predator responses) have been ascribed developmental effects of such deficiencies and various kinds of environmental enrichment have been used to reverse these deficits (reviewed by Huntingford, 2004).

Domain 3. Disease, injury and functional impairment. Disease should be prevented or rapidly diagnosed and treated.

Diseases frequently indicate an underlying environmental problem, so diagnosing and controlling a disease must always take account of the whole system and not consider the fish alone. Diseases of fish are mostly species and system specific and many are poorly understood, but methods of prevention are available for an increasing number (Biering et al., 2005; Håstein et al., 2005).

Domain 4. Behavioural/interactive restriction. Animals should have sufficient space, proper facilities and where appropriate, the company of the animal's own kind.

Many species form dense schools in the wild and this is important when assessing the welfare of such species if held at high density in captivity, since being held at densities that are too low rather than too high may impair welfare. This is a case where it can be misleading to extrapolate from birds and mammals to fish. As discussed in Section 1, we do not know whether fish such as salmon are motivated to migrate by a particular route (as opposed to finding food or swimming long distances, which they can do in farm cages for example); if this were the case, their behavioural needs might not be met in a sea cage. The concept of 
"facilities" may be inappropriate for fish, though some species need shelter or cover, some may require nesting material when breeding, some need tough structures on which to chew (Etscheidt, 1995).

Domain 5. Mental and physical suffering. Conditions that produce unacceptable levels of anxiety, fear, distress, boredom, sickness, pain, thirst, hunger and so on should be minimised.

Domain 5 is critical since it relates adverse experience to emotional response. As discussed in section 2, the subjective experiences of fish are very hard to understand, so it is not easy to identify "conditions that produce unacceptable levels of anxiety... and so on." Most of the cues that are employed to identify distress and fear responses in other vertebrates are simply not accessible for fish - for example, there are no direct parallels for facial or vocal signalling. Greater understanding of cognitive processes in fish is needed before we can make the link between welfare and suffering in this group.

\section{Conclusions}

There are more than 30,000 species of teleost fish and we only know a little about conditions that promote welfare for just a few of these, but even so a picture is beginning to emerge (partial and blurred at present) of how various human activities impinge on the welfare of fish and therefore of what might be done to improve matters. This review highlights the need for better knowledge and a fuller understanding of fish welfare. Some of these areas of ignorance concern issues that are fundamental to the whole concept of fish welfare, what it means and how it might be measured. These are listed below:

1. The single most important area of ignorance is a lack of understanding of the mental capabilities of fish and how objectively measurable responses to challenges (physical damage and physiological and behavioural responses) are associated with subjective states of well-being or suffering.

2. After that, given the importance of the concepts of natural being good, for each exploited species, it is important to discover whether there are actions that the fish are highly motivated to perform and that, like nest building in domestic hens, may be described as 'behavioural needs'.

3. We also need to know more about diseases in fish, about the links between stress, immune function and disease states and therefore about the relationship between health and welfare.

4. In practical terms, a better array of welfare indicators (for example, easily observed morphological and behavioural cues) is requires for everyday use in circumstances where time consuming scrutiny of fish using laboratory-based tests is impossible.

5. Other gaps in existing knowledge are also important, but will be somewhat easier to fill because they involve expanding the information already available for some species and in some contexts.

6. A certain amount is known about the effect of angling and aquaculture practices on fish welfare, but there is very little information on the welfare of ornamental fish, especially from capture to point of sale. Questions also remain about conditions within aquaria and ornamental ponds. What are the 
Danish Centre for Bioethics and Risk Assessment

This is a post-print version of an article published in

Journal of Fish Biology by Wiley-Blackwell

For more articles on animal ethics, see www.animalethics.net

effects of being confined in a small, exposed space, of social isolation or of frequent interactions with a predator?

7. As with the welfare of ornamental fish there is very little information on the welfare of fish in the context of commercial fisheries

8. Where both angling and aquaculture are concerned, we know a reasonable amount about welfare of salmonids, but very little about other kinds of fish that are reared commercially or caught by anglers.

9. Even for the well studied species and well documented effects, the exact mechanisms by which the adverse effects come about are unknown. For example, there is plenty of evidence of poor welfare in salmon and trout held at very high densities, but it is not clear whether this is the result of poor water quality, high levels of aggression, simple physical damage or some other process (Ellis et al. 2002). It is important to clarify such issues in order to decide on appropriate remedial measures.

By spelling out current understanding on the welfare of fish, we hope that this review will contribute to debate on the subject. This is a difficult area to review, because many academic disciplines have an interest in it, because complex concepts are involved that are hard to define and because there are large areas of ignorance and, consequently, of disagreement. In this document a pragmatic working position has been taken on a number of important questions (whether fish suffer and whether this matters, for example), recognising that this position may have to be changed in the light of facts that emerge in the future. In spite of these difficulties, a great deal of painstaking research has shown how fish respond to the adverse events that they experience in nature and how these could be used to probe their welfare. 


\section{References}

Association for the Study of Animal Behaviour (ASAB) (2001). "Guidelines for the treatment of animals in behavioural research and teaching". Animal Behaviour 61, 271-275.

Abbott, J.C. \& Dill, L.M. (1989). The relative growth of dominant and subordinate juvenile steelhead trout (Salmo gairdneri) fed equal rations. Behaviour 108, 104-111.

Adams, C.E. \& Huntingford, F.A. (2005). Behavioural syndromes in farmed fish: implications for production welfare. Behaviour 142 (9-10), 1207-1221 (15).

Adams, C.E., Fraser, D., Huntingford, F.A., Greers, R.B., Askew, C.M. \& Walker, A.F. (1998). Trophic polymorphism amongst Arctic charr from Loch Rannoch, Scotland. Journal of Fish Biology 52, 1259-1271. doi:10.1111/j.1095-8649.tb00970.x

Adams, C.E., Turnbull, J., Bron, J. \& Huntingford, F. A. (In Review). Stocking density, husbandry and the welfare of farmed Atlantic salmon: a multivariate approach to welfare in a controlled tank experiment. Aquaculture 00, 000-000.

Alanara, A. (1997). Feeding behaviour and growth performance in fish within a dominance hierarchy. In Voluntary Food Intake in Fish. (Houlihan, D., Kiessling, A., \& Boujard, T. eds), pp. 10. Oxford: Blackwell Science Ltd.

Andrews, J.E., Kadri, S., Jewel, H \& Huntingford, F.A. (2002). The effects on demand feeding on swimming speed and feeding responses in Atlantic salmon (Salmo salar L.), gilthead sea bream (Spartus aurathus L.) and European sea bass (Dicentrarchus labrax L.) in sea cages. Aquaculture Research 33, 501-507. doi:10.1046/j.1365-2109.2002.00740.x

Appleby, M.C. (1999). Tower of Babel: Variation in ethical approaches, concepts of welfare and attitudes to genetic manipulations. Animal Welfare 8, 381-390.

Appleby, M.C. \& Sandøe, P. (2002). Philosophical debate on the nature of well-being: implications for animal welfare. Animal Welfare 11, 283-294.

Balm, P.H.M. \& Pottinger, T.G. (1995). Corticotrope and melanotrope POMC-derived peptides in relation to interrenal function during stress in rainbow trout (Oncorhynchus mykiss). General Comparative Endocrinology 98, 279-288.

Bandeen, J. \& Leatherland, J.F. (1997). Transportation and handling stress of white suckers raised in cages. Aquaculture International 5, 385-396.

Barnett, C.W. \& Pankhurst, N.W. (1998). The effects of common laboratory and husbandry practices on the stress response of greenback flounder (Rhombosolea tapirinia, Günther 1862). Aquaculture 162, 113-329.

Barton, B. (1997). Stress in sunfish: past, present and future - a historical perspective. In Fish Stress and Health in Aquaculture, Society for Experiment Biology, Seminar Series 62. (Iwama, 
G.K., Pickering, A.D., Sumper, J.P., \& Schreck, C.B. eds), pp. 1-31. Cambridge: Cambridge University Press.

Barton, B.A. (2000). Salmonid fishes differ in their cortisol and glucose responses to handling and transport stress. North American Journal of Aquaculture 62, 12-18.

Bermond, B (1997). The myth of animal suffering. In Animal Conscienceness \& Animal Eyhics (Dol, M., Kasanmoentalib, S., Lijmbach, S., Rivas, E., \& van den Bos, R. eds), pp. 125-143. Assen: Van Gorcum.

Beukema, J.J. (1970). Angling experiments with carp: decreased catchability through one trial learning. Netherlands Journal of Zoology 20, 81-92.

Bevelhimer, M.A. (1996). Relative importance of temperature, food and physical structure to habitat choice by smallmouth bass in laboratory experiments. Transactions of the American Fisheries Society 125, 274-283.

Biering, E., Villoing, S., Sommerset, I. \& Christie, K.E. (2005). Update on viral vaccines for fish. Developmental Biology 121, 97-113.

Bogloine, C., Gagliardi, F., Scardi, M. \& Cataudella, S. (2001). Skeletal descriptors and quality assessment in larvae and post-larvae of wild and reared gilthead bream (Sparus aurata L.). Aquaculture 192, 1-22.

Borski, R.J. \& Hodson, R.G. (2003). Fish research and the institutional animal care and use committee. Ilar Journal 44, 286-294.

Braithwaite, V.A. (2006). Cognitive ability in fish. Fish Physiology 24, 1-37.

Braithwaite, V.A. \& Huntingford, F.A. (2004). Fish and welfare: do fish have the capacity for pain perception and suffering. Animal Welfare 13, 587-592.

Brett, J.R. (1979). Environmental factors and growth. In Rainbow trout growth in circular tanks. Consequences of different loading densities. US Department of the Interior, Fish and Wildlife Technical Report 86, 16.

Broadhurst, M.K. \& Barker, D.T. (2000). Effects of capture by hook and line on plasma cortisol, scale loss and survival in juvenile mulloway (Agrysomus hololepidotus). Archive of Fishery and Marine Research 48, 1-10.

Broglio, C., Rodriguez, F. \& Salas, C. (2003). Spacial cognition and its neutral basis in teolost fishes. Fish and Fisheries 4, 247-255. doi:10.1046/j.1467-2979.2003.00128.x

Broom, D.M. (1998). Welfare, stress and the evolution of feelings. Advances in the Study of Behaviour 27, 371-403.

Brown, C. \& Warburton, K. (1999). Social mechanisms enhance escape responses in shoals of rainbowfish (Melanotaenia duboulayi). Environmental Biology of Fishes 56, 455-459. 
Burt de Perera, T. (2004). Fish can encode order in their spacial map. Proceedings of the Royal Society London B. 271, 2131-2134.

Cahu, C., Infante, J. Z. \& Takeuchi, T. (2003). Nutritional components affecting skeletal development in larval fish. Aquaculture 227 (1-4), 245-258.

Carss, D. N. (1993). Cormorants Phalacrocorac carbo at cage fish farms in Argyll, western Scotland. Seabird 15, 38-44.

Chandroo, K.P., Cooke, S.J., McKinley, R.S. \& Moccia, R.D. (2005). Use of electromyogram telemetry to assess the behavioural and energetic reponses of rainbow trout, Oncorhynchus mykiss (Walbaum) to transportation stress. Aquaculture Research 36, 1226-1238. doi:10.1111/j.1365-2109.2005.01347.x

Chandroo, K.P., Duncan, I.J.H. \& Moccia, R.D. (2004a). Can fish suffer?: perspectives on sentience, pain, fear and stress. Applied Animal Behaviour Science 86, 225-250.

Chandroo, K.P., Yue, S. \& Moccia, M.D. (2004b). An evaluation of current perspectives on consciousness and pain in fishes. Fish and Fisheries 5 (4), 281-295. doi:10.1111/j.14672679.2004.00163.x

Chopin, F.S. \& Arimoto, T. (1995). The condition of fish escaping from fishing gears - a review. Fisheries Research 21, 315-327.

Christenson, J., Boman, A., Langerback, P. \& Grillner, S. (1988). The dorsal cell, one class of primary sensory neuron in the lamprey spinal cord I. Touch, pressure but no nociception - a physiological study. Brain Research 440, 1-8.

Conte, F.S. (2004). Stress and the welfare of cultured fish. Applied Animal Behavioural Science 86, 205-223.

Cooke, S.J. \& Philipp, D.P. (2004). Behavior and mortality of caught-and-release bonefish (Albula spp.) in Bahamian waters with implications for a sustainable fishery. Biological Conservation 118, 599-607.

Cubitt, F.S. (2002). Individual growth patterns in farmed Atlantic salmon: the role of social interactions. PhD Thesis, University of Glasgow.

Czanyi, V. \& Doka, A. (1993). Learning interactions between prey and predator fish. Marine Behaviour and Physiology 23, 63-78.

Davis, K.B., Griffin, B.R. \& Gray, W.L. (2002). Effect of handling stress on susceptibility of cannel catfish Ictalurus punctatus to Ichthyophthirius multifiliis and channel catfish virus infection. Aquaculture 214, 55-66.

Dawkins, M.S. (1998). Evolution and animal welfare. Quarterly Review of Biology 73, 305-328.

Dawkins, M.S. (2004). Using behaviour to assess animal welfare. Animal Welfare 13, 3-7. 
De Silva, S. S. and Anderson, T. A. (1995). Fish Nutrition in Aquaculture. London: Chapman and Hall.

DuBois, R.B., Margenau, T.L., Stewart, R.S., Cunningham, P.K. \& Pasmussen, P. W. (1994). Hooking mortality of northern pike angled through the ice. North American Journal of Fish Management 14, 769-775.

Duncan, I. J. H. and Fraser, D. (1997). Understanding animal welfare In Animal Welfare (Appleby, M.C. \& Hughes, B.O. eds), pp. 19-47. Wallingford, Oxon: CAB International.

Dutil, J.D. \& Lambert, D. (2000). Natural mortality from poor condition in Atlantic cod (Gadus morhua). Canadian Journal of Fisheries \& Aquaculture Science 57, 826-836.

Ehrensing, R.H., Michell, G.F. \& Kastin, A.J. (1982). Similar antagonism of morphine analgesia by MIF - 1 and naloxone in Carassius auratus. Pharmacology, Biochemistry and Behaviour 17, 757-761.

Einen, O., Waagan, B. \& Thamassam, M.S. (1998). Starvation prior to slaughter in Atlantic salmon (Salmo salar) - Effects on weight loss, body shape, slaughter- and fillet- yield, proximate and fatty acid composition. Aquaculture 166, 85-104.

Ellis, T., James, J.D., Stewart, C. \& Scott, A.P. (2004). A non-invasive stress assay based upon measurement of free cortisol released into the water by rainbow trout. Journal of Fish Biology 65, 1233-1252. doi:10.1111/j.0022-1112.2004.tb00499.x

Ellis, T., North, B., Scott, A.P., Bromage, N.R., Porter, M. \& Gadd, D. (2002). The relationships between density and welfare in farmed rainbow trout. Journal of Fish Biology 61, 493-531. doi:10.1111/j.1095-8649.2002.tb00893.x

Endler, J. A. (1986). Defence against predators. In Predator, Prey Relationships. (Feder, M.E. \& Lauder, G.V. eds), pp. 109-134. Chicago: University of Chicago Press.

Erdmann, M.V. (2002). Clove oil: an 'eco-friendly' alternative to cyanide use in the live reef fish industry. The Secretariat of the Pacific Community. Costal Fisheries Programme. (http://www..spc.org.nc/coastfish/News/Irf/5/1Clove.htm).

Errea, A. \& Danulat, E. (2001). Growth of the annual fish Cynolebias viarius (Cyprodontiformes) in the natural habitat compared with laboratory conditions. Environmental Biology of Fishes 61, 261-268.

Etscheidt, J. (1995). Kriterien zur Beurteilung der Haltung von Susswasseraquarienfischen im Zoohandel. Tierarztl Prax 50, 196-199.

Etscheidt, J. \& Manz, D. (1992). Suswasseraquaristik und tierarzliche Praxis. Teil 2: Untersuchungen zur artgerechten Haltung von Zierfuschen. Tierarztl Prax 20, 221-226.

Ewing, R.D. \& Ewing, S.K. (1995). Review of the effects of rearing density on the survival to adulthood for Pacific salmon. Progressive Fish-Culturist 57, 1-25. 
Food and Agriculture Organisation of the United Nations (2004). The State of World Fisheries and Aquaculture (Sofia), pp 153.

Farbridge, K.J. \& Leatherland, J.F. (1992). Plasma growth hormone levels in fed and fasted rainbow trout (Oncorhynchus mykiss) are decreased following handling stress. Fish Physiology and Biochemistry 10, 67-73.

Ferguson R.A., Kieffer, J.D. \& Tuffs, B.L. (1993). The effects of body size on the acid-base and metabolite status in the white muscle of rainbow trout before and after exhaustive excerise. Journal of Experimental Biology 180, 195-207.

Fernö, A., Huse, I., Juell, J.E. \& Bjordal, Å. (1995). Vertical distribution of Atlantic salmon (Salmo Salar L.) in net pens: Trade-off between surface light avoidance and food attraction. Aquaculture 132, 285-296.

Ferrez de Olivera, E. (1995). Studies on parasites of ornamental fish from South America with potential for transfaunation. PhD Thesis, University of Sterling.

FitzGibon, D. (1993). UK restriction proposals. Ornamental Fish International Journal 10, 12-14.

Foggitt, R. (1997). Fish health in a new aquarium. Aquarist and Pondkeeper 61, 34-36.

Fraser, D. (1999). Animal ethics and animal welfare science: Bridging the two cultures. Applied Animal Behavioural Science 65, 171-189.

Fraser, D., Weary, D.M., Pajor, E.A. \& Miligan, B.N. (1997). A scientific conception of animal welfare that reflects ethical concerns. Animal Welfare 6, 174-186.

Furevik, D.M., Bjordal, Å., Huse, I. \& Fernö, A. (1993). Surface activity of Atlantic salmon (Salmo salar L.) in net pens. Aquaculture 110, 119-128.

Garcia de Leaniz, C.G. (1990). Distribution, growth, movements and homing behaviour of juvenile Atlantic salmon and brown trout in the Girnock Burn, Aberdeenshire. PhD Thesis, University of Aberdeen.

Garcia-Garbi, N., Inglis, V., and Turnbull, J. F. (1998). Assessment of phagpocytosis by fluorchrome acridine orange. In Methodology in Fish Disease Research (Barnes, A. ed), pp. 91-96. Aberdeen: Fish Research Services.

Gauldie, R.W. \& Jones, J.B. (2000). Stocks of geographically separated populations of the New Zealand Orange roughy (Hoplostethus atlanticus) in relation to parasite infestation, growth rate and otolith shape. Bulletin of Marine Science 67, 949-971.

Giattina, J.D. \& Garon, R.R. (1983). A review of the preference-avoidance responses of fishes to aquatic contaminants. Residue Reviews 87, 43-90.

Gomez-Laplaze, L.M. \& Morgan, E. (1993). Transfer and isolation effects on the feeding behaviour of the angelfish (Pterophyllum scalare). Experiementia 49, 817-819. 
Goodey, W. \& Liley, N.R. (1985). Grouping fails to influence the escape behaviour of the guppy (Poecilia reticulata). Animal Behaviour 33, 1032-1033.

Gornati, R., Papis, E., Rimoldi, S., Terova, G., Sargolia, M. \& Bernadini, G. (2004). Rearing density influences the expression of stress-related genes in sea bass (Dicentrarchus labrax L.). Gene 1, 111-118.

Greaves, K. (2001). Manipulating aggression among juvenile Atlantic halibut (Hippoglossus hippoglossus) in culture conditions. PhD Thesis, University of Glasgow.

Greaves, K. \& Tuene, S. (2001). The form and context of aggressive behaviour in farmed Atlantic halibut (Hippoglossus hippoglossus). Aquaculture 193, 139-147.

Griffin, B.R., Davis, K.B., Darwish, A. \& Straus, D.L. (2002). Effect of exposure to potassium permanganate on stress indicators in channel catfish. Journal of the World Aquaculture Society 33, 1-9.

Griffin, B.R., Davis, K.B. \& Schlenk, D. (1999). Effect of simulated copper sulphate on stress indicators in channel catfish. Journal of Aquatic Animal Health 11, 231-236.

Gustaveson, A.W., Wydoski, R.S. \& Wedemyer, G.A. (1991). Physiological responses of the largemouth bass to angling stress. Transaction of the American Society 120, 629-636.

Gwak, W.S. (2003). Effects of shelter on growth and survival in age-0 black sea bass, Centropristis striata (L.). Aquaculture Research 34, 1387-1390.

Handy, R.D. \& Depledge, M.H. (1999). Physiological responses: Their measurement and use as environmental biomarkers in ecotoxicology. Ecotoxicology 8, 329-349.

Hanlon, R. T. and Messenger, J. B. (1996). Cephalapod Behaviour. Cambridge: Cambridge University Press.

Hart, P.J.B. (1993). Teleost foraging: Facts and theories. In Behavioural of Teleost Fishes. (Pitcher, T.J. ed), London: $2^{\text {nd }}$ edn. Chapman \& Hall.

Hart, P.J.B. (1997). Foraging Tactics. In Behavioural Ecology of Teleost Fishes. (Godin, J.-G.J. ed), Oxford: Oxford University Press.

Håstein, T., Gudding, R. \& Evensen, O. (2005). Bacterial vaccines for fish - an update of the current situation worldwide. Developmental Biology 121, 55-74.

Heeger, R. \& Brom, F.W.A. (2001). Intrinsic value and direct duties: from animal ethics towards environmental ethics? Journal of Agriculture and Environmental Ethics 14, 241-252.

Hignette, M. (1984). Utilisation du cyanure pour la capture des poissons tropicaux marins destnes a l'aquariologie: methodes de diagnostic. Oceanis 10, 585-591.

Holm, J.C., Tuene, S. \& Fosseidengen, J.E. (1998). Halibut behaviour as a means of asssessing suitability of ongrowth systems. Annual Science Conference, ICES. Casias, Portugal 16-19 Sept. 
Hughes, B.O., Duncan, I.J.H. \& Brown, M.F. (1989). The performance of nest building by domestic hens: is it more important than the construction of a nest? Animal Behaviour 37, 210-214.

Hulbert, P.J. \& Engstrom-Heg, R. (1980). Hooking mortality of worm-caught hatchery brown trout. New York Fish and Game 27, 1-10.

Iguchi, K. \& Mizuno, N. (1999). Early starvation limits survival in amphidromous fishes. Journal of Fish Biology 54, 705-712. doi:10.1111/j.1095-8649.1999.tb02027.x

Iverson, M., Finstad, B. \& Nilssen, K.J. (1998). Recovery from loading and transport stress in Atlantic salmon (Salmo salar L.) smolts. Aquaculture 168, 387-394.

Jackson, C. (2003). Laboratory fish: impacts of pain and stress on well-being. Contemporary Topics $42(3), 62-73$.

Jergensen, E.H., Christiansen, J.S. \& Jobling, M. (1993). Effects of stocking density on food intake, growth performance and oxygen consumption in Artic charr (Salvilinus alpinus). Aquaculture 110, 191-204.

Jonsson, N., Jonsson, B. \& Hansen, L.P. (1991). Energetic cost of spawning in male and female Atlantic salmon (Salmo salar L.). Journal of Fish Biology 39, 739-744.

Juell, J.-E. \& Fosseidengen, J.E. (2004). Use of artificial light to control swimming depth and fish density of Atlantic salmon (Salmo salar) in production cages. Aquaculture 233, 269-282.

Juell, J.-E., Oppedal, F., Boxaspen, K. \& Taranger, G.L. (2003). Submerged light increases swimming depth and reduces fish density of Atlantic salmon Salmo salar L. in production cages. Aquaculture Research 34, 469-477. doi:10.1046/j.1365-2109.2003.00833.x

Kadri, S., Mitchell, D.F., Metcalfe, N.B., Huntingford, F.A. \& Thorpe, J.E. (1996). Differential patterns of feeding and resource accumulation in maturing and immature Atlantic salmon, Salmo salar. Aquaculture 142 (3), 245-257.

Koolhaas, J.M., Korte, S.M., De Boer, S.F., van der Vegt, B.J., van Reenen, C.G., Hopster, J., De Johng, I.C., Ruis, M.A.W. \& Blokhuis, H.J. (1999). Coping styles in animals: current status in behaviour and stress-physiology. Neuroscience and Behaviour Reviews 23, 925-935.

Kotrschal, K., van Straaden, M.J. \& Huber, R. (1998). Fish brains: evolution and environmental relationships. Reviews in Fish Biology and Fisheries 8, 373-408.

Kramer, D.L. (1987). Dissolved oxygen and fish behaviour. Environmental Biology of Fishes 18, 8192.

Kristiansen, T.S., Ferno, A., Holm, J.C., Trivitera, L., Bakke, S. \& Fosseidengen, J.E. (2004). Swimming behaviour as an indicator of low growth rate and impaired welfare in Atlantic halibut (Hippoglossus hippoglossus L.) reared at three stocking densities. Aquaculture 230, 137-151. 
Kristiansen, T.S. \& Juell, J.E. (2002). How can we document the welfare of farmed fish? In Seafarming Today and Tomorrow. pp 285-286. Compiled: Basurka, B. \& Saroglia, M. European Aquaculture Society Special Publication 32, August 2002.

Kuperman, B.I., Matey, V.E. \& Hurlbert, S.H. (2001). Parasites of fish from the Salton Sea California, USA. Hydrobiologia 466, 195-208.

Lillie, J.H. \& Roberts, R.J. (1997). Pathogenicity and culture studies comparing the Aphanomyces involved in epizootic ulcerative syndrome (EUS) with other similar fungi. Journal of Fish Diseases 20, 135-144. doi:10.1046/j.1365-2761.1997.d01-116.x

Lima, S.L. (1998). Predator induced stress and behaviour. Advances in the Study of Behaviour 27, 215-290.

Lines, J.A., Robb, D.H., Kestin, S.C., Crook, S.C. \& Benson, T. (2003). Electric stunning: a humane slaughter method for trout. Aquaculture Engineering 28, 141-154.

Lowe-McConnell, R. H. (1991). Ecology of cichlids in South America and African waters, excluding the African Great Lakes. In Cichlid fishes - behavior, ecology and evolution. (Keenleyside, M.H.A. ed), pp. 60-85. London: Chapman \& Hall.

Maceina, M.J. \& Burn, D.R. (2001). Changes in the black bass community and fishery with oligotrophication in West Point Reservoir, Georgia. North American Journal of Fisheries Management 21, 745-755.

Margolis, L., Esch, G.W., Holmes, J.C., Kurtis, A.M. \& Shad, G.A. (1982). The use of ecological terms in Parasitology. Journal of Parasitology 68, 131-133.

Matthews, G. \& Wickelgren, W.O. (1978). Trigeminal sensory neurons of the sea lampray. Journal of Comparative Physiology 123, 329-333.

Mellor, D.J. \& Stafford, K.J. (2001). Integrating practical, regulatory and ethical strategies for enhancing farm animal welfare. Australian Veterinary Journal 79, 762-768.

Melotti, P., Roncarati, A., Garella, E., Carnevali, O., Mosconi, G. \& Polzonetti-Magni, A. (1992). Effects of handling and capture stress on plasma glucose, cortisol and androgen levels in brown trout (Salmo trutta morpha fario). Journal of Applied Ichthyology 8, 234-239.

Mench, J. A. and Mason, G. J. (1997). Behaviour. In Animal Welfare (Appleby, M.C. \& Hughes, B.O. eds), pp. 127-142. Wallingford, Oxon, UK: New York: CAB International.

Mesa, M.G. \& Schreck, C.B. (1989). Electrofishing mark-recapture and depletion methodologies evoke behavioural and physiological changes in cutthroat trout. Transactions of the American Fisheries Society 118, 644-658.

Metcalfe, N.B. \& Thomson, B.C. (1995). Fish recognize and prefer to shoal with poor competitors. Proceedings of the Royal Society B. 259 (1355), 207-210. 
Metcalfe, N.B., Huntingford, F.A. \& Thorpe, J.E. (1987). The influence of predation risk on the feeding motivation and foraging strategy of juvenile Atlantic salmon. Animal Behaviour 35, 901-911.

Metcalfe, N.B., Huntingford, F.A. \& Thorpe, J.E. (1988). Feeding intensity, growth rates, and the establishment of life-history patterns in juvenile Atlantic salmon Salmo salar. Journal of Animal Ecology 57, 463-474.

Mintel 1991. 213 W. Institute Place Suite 208 Chicago, IL 60610.

Moberg, G.P. (1999). When does an animal become stressed? Lab. Animal 23, 22-26.

Montero, D., Izquierdo, M.S., Tort, L., Robaina, L. \& Vergara, J.M. (1999). High stocking density produces crowding stress altering some physiological and biochemical parameters in gilthead seabream, Sparua aurata, juveniles. Fish Physiology and Biochemistry 20, 53-50.

Montgomery, M. \& Needleman, M. (1997). Welfare effects of toxic contamination in freshwater fish. Land Economics 77, 211-223.

Morton, D.B. (1990). Guidelines on the recognition of pain, distress and discomfort in experimentalanimals. European Journal of Pharmacology 183, 1583-

Muonehke, M.I. \& Childless, W.M. (1994). Hooking mortality: a review for recreational fisheries. Reviews in Fisheries Science 2, 123-156.

Narveson, J. (1983). Animal rights revisited. In Ethics and animals. (Miller, H.B. \& Williams, W.H. eds), Clifton, New Jersey: Humana Press.

National Rivers Authority (1995). National Angling Survey 1994. NRA fisheries Technical Report 5, pp 31 .

Neat, F.C., Taylor, A.C. \& Huntingford, F.A. (1998). Proximate costs of fighting in male cichlid fish: the role of injuries and energy metabolism. Animal Behaviour 55, 875-882.

Nickum, J.G. (1988). Guidelines for Use of Fishes in Field Research. Fisheries 13, 16-23.

O'Connor, K.I., Metcalf, N.B. \& Taylor, A.C. (2000). The stability of standard metabolic rate during a period of food deprivation in juvenile Atlantic salmon. Journal of Fish Biology 57, 41-51. DOI:10.1111/j.1095-8649.2000tb00774.x

Odling_Smee, L. \& Braithwaite, V.A. (2003). The role of learning in fish orientation. Fish and Fisheries 4, 235-246. doi:10.1046/j.1467-2979.2003.00127.x

Okawara, Y., Ko, D., Morley, S.D., Richter, D. \& Lederis, K. (1992). In situ hybridisation of corticopin-releasing factor encoding messenger RNA in the hypothalamus of the white sucker (Catostamus commersoni). Cell and Tissue Research 267, 545-549.

Oliveira, R. F., Canario, A. V. M., and Bsharry, R. (1999). Hormones, behvaviour and conservation of littoral fishes: current status and prospects for future research. In Behaviour and 
Conservation of Littoral Fishes. (Almada, V.C., Oliveria, R.F., \& Gonçalves, E.J. eds), pp. 149-168. Apilcada: Instituto Superior de Psicologia Apilcada.

Olla, B.L. \& Davis, M.W. (1989). The role of learning and stress in predator avoidance hatcheryreared coho salmon (Oncorhynchus kisutch) juveniles. Aquaculture 76, 209-214.

Orban, E., Di Lena, G., Nevigato, T., Casini, I., Santaroni, G., Marxetti, A. \& Caproni, R. (2002). Quality characteristics of sea bass intensively reared and from a lagoon as affected by growth conditions and the aquatic environment. Journal of Food Science 67, 542-546.

Øverli, O., Winberg, S. \& Pottinger, T.G. (2005). Behavioral and neuroendocrine correlates of selection for stress responsiveness in rainbow trout - a review. Integrative and Comparative Biology 45, 463-474.

Pankhurst, N.W. \& Dedual, M. (1994). Effect of capture and recovery on plasma levels of cortisol, lactate and gonadal steriods in a natural population of rainbow trout. Journal of Fish Biology 45, 1013-1025. doi:10.1111/j.1095-8649.1994.tb01069.x

Perry, S. \& Bernier, N.J. (1999). The acute hormonal adrenergic stress response in fish: facts and fiction. Aquaculture 177, 285-295.

Pickering, A. D. (1998). Stress responses in farmed fish. In Biology of Farmed Fish (Black, K.D. \& Pickering, A.D. eds), pp. 222-255. Sheffield: Sheffield Academic Press.

Pickering, A.D. \& Pottinger, T.G. (1985). Acclimation of the brown trout (Salmo trutta L.) to the stress of daily exposure to malachite green. Aquaculture 44, 145-152.

Pickering, A.D. \& Pottinger, T.G. (1989). Stress response and disease resistance in salmonid fish: effects of chronic elevation of plasma cortisol. Fish Physiology and Biochemistry 7, 253258.

Pickering, A.D., Pottinger, T.G., Sumpter, J.P., Carragher, J.F. \& LeBail, P.Y. (1991). Effect of acute and chronic stress in the levels of circulating growth hormone in the rainbow trout (Oncorhynchus mykiss). Fish Physiology and Biochemistry 83, 86-93.

Pitcher, T. J. and Parrish, J. K. (1993). Functions of shoaling behaviour in teleosts. In Behaviour of Teleost (Pitcher, T.J. ed), pp. 363-439. London: Chapman \& Hall.

Plumb, J. A. (1994). Health maintenance of cultured fish: Principle microbial diseases. Boca Raton, Florida: CRC Press.

Poli, B. M., Zampacavello, G., Iurzan, F., de francesco, M, Mosconi, G., and Parisi, G. (2002). Biochemical stress indicators changes if sea bass as influenced by slaughter method. In Seafarming Today and Tomorrow. (Basurco, B. \& Sargolia, M. eds), pp. 429-430. European Aquaculture Society Special Publication 32. 
Portavella, M., Torres, B. \& Salas, C. (2004). Avoidance Response in Goldfish: Emotional and Temporal Involvement of Medial and Lateral Telencephatic Pallium. The Journal of Neuroscience 24(9), 2342-2335.

Pottinger, T.G. (1998). Changes in blood cortisol, glucose and lactate in carp retained in anglers keep nets. Journal of Fish Biology 53, 728-742. doi:10.1111/j.1095-8649.1998.tb10828.x

Pottinger, T. G. (1999). The impact of stress on animal reproductive activities. In Stress Physiology

(Balm, P.H.M. ed), pp. 130-177. Sheffield: Sheffield University Press.

Pottinger, T.G. \& Calder, G.M. (1995). Physiological stress in fish during toxicological procedures: A potentially confounding factor. Environmental Toxicology and Water Quality 10 (2), 135146.

Pottinger, T.G. \& Carrick, T.R. (1999). Modification of the plasma cortisol response to stress in rainbow trout by selective breeding. General and Comparative Endocrinology. 116, 122132.

Pottinger, T.G., Knudsen, F.R. \& Wilson, J. (1994). Stress-induced changes in the affinity and abundance of cytostolic cortisol-binding sites in the liver of rainbow trout (Oncorhynchus mykiss) Walbaum, are not accompanied by changes in measurable nuclear binding. Fish Physiology and Biochemistry 12, 511-

Pottinger, T.G. \& Moran, T.A. (1993). Differences in plasma cortisol and cortisone dynamics during stress in two strains of rainbow trout (Oncorhynchus mykiss). Journal of Fish Biology 43, 121-130. doi:10.1111/j.1095-8649.tb00415.x

Press, C. McL. (1998). Immunology of fishes. In Handbook of vertebrate immunology. (Pastoret, P.P., Griebel, P., Bazin, H., \& Govaerts, A. eds), pp. 3-61. London, UK: Academic Press LTD.

Pronovi, F., Raicevich, S., Da Ponte, F., Boscolo, R., Franceschini, G., Torricelli, P. \& Giovanardi, O. (2001). Effects of mechanical clam harvesting on bottom sediment in the Venice lagoon. In $36^{\text {th }}$ CIEMS Congress Proceedings. pp 410. Monaco: Multiprint.

Puste, A.M. \& Das, D.K. (2001). Impact of air pollutant emissions on the ecosystems in the vicinity of industrial areas of Indian sub-tropics. Water Air Soil Pollution 130, 843-848.

Puvanendran, V. \& Brown, J.A. (2002). Foraging, growth and survival of Atlantic cod larvae reared in different light intensities and photoperiods. Aquaculture 214, 131-151.

Reese, E.S. (1989). Orientation behaviour of butterfly fishes (family Chaetodontidae) on coral reefs spacial learning of route specific landmarks and cognitive maps. Environmental Biology of Fishes 25, 79-86.

Regan, T. (1989). The Case for Animal Rights. In Animal Rights and Human Obligations. (Regan, T. \& Singer, P. eds), Englewood Cliffs: Prentice Hall. 
Reimchem, T. E. (1994). Predators and morphological behaviour in the threespine stickleback. In The Evolutionary Biology of the Threespine Stickleback. (Bell, M.A. \& Foster, S.A. eds), pp. 207-240. Oxford: Oxford University Press.

Ribas, L., Planas, J.V., Barton, B., Monetti, C., Bernadini, G., Sargolia, M., Tort, L. \& MacKenzie, S. (2004). A differentially expressed enolase gene isolated from the gilthead sea bream (Sparus aurata) under high-density conditions is up-regulated in brain after in vivo lipopolycsaccharide challenge. Aquaculture 241, 195-206.

Robb, D., Kestin, S. \& Lines, J. (2000). Progress with humane slaughter. Fish Farmer Nov/Dec, pp 41.

Rodriguez, F., Duran, E., Vargas, J.P., Torres, B. \& Salas, C. (1994). Performance of goldfish trained in allocentric and egocentric maze procedures suggests the presence of a cognitive mapping system in fishes. Animal Learning \& Behaviour 22, 409-420.

Rodriguez-Moldes, I., Manso, M.J., Becerra, M., Molist, P. \& Anadon, R. (1993). Distribution of substance P-like immunoreactivity in the brain of the elasmobranch Soyliorhinus anicula. Journal of Comparative Neurology 335 (2), 228-244.

Rollin, B.E. (1993). Animal welfare, science and value. Journal of Agriculture and Environmental Ethics 6, 44-50.

Rose, J.D. (2002). The neurobehavioural nature of fishes and the question of awareness and pain. Reviews in Fisheries Science 10, 1-38.

Ross, L. G. (2000). Environmental physiology and energetics. In Tilapias: Biology and Exploitation, Fish and Fisheries Series 25 (Beveridge, M.C.M. \& McAndrew, B.J. eds), pp. 89-128. Dordrecht, The Netherlands: Kluwer Academic Press.

Rotllant, J. \& Tort, L. (1997). Cortisol and glucose responses after acute stress by net handling in the sparid red porgy previously sunjected to crowding stress. Journal of Fish Biology 51, 21-28. doi:10.1111/j.1095-8649.1997.tb02510.x

Rouger, Y., Aubin, J., Breton, B., Fauconneau, B., Fostier, A., Le Bail, P., Loir, M., Prunet, P. \& Maisse, G. (1998). Response of rainbow trout (Oncorhynchus mykiss) to transport stress. Bulletin Francais de la Peche et de la Pisciculture (350-351), 511-519.

Ruane, N.M., Carballo, E.C. \& Komen, J. (2002). Increased stocking density influences the acute physiological stress response of common carp (Cyprinus carpio L.). Aquaculture Research 33, 777-784. doi:10.1046/j.1365-2109.2002.00717.x

Sandodden, R., Findstad, B. \& Iversen, M. (2001). Transport stress in Atlantic salmon (Salmo salar L.): anaesthesia and recovery. Aquaculture Research 32, 87-90. doi:10.1046/j.13652109.2001.00533.x 
Sandøe, P, Crisp, R., and Holtug, N. (1997). Ethics In Animal Welfare (Appleby, M.C. \& Hughes, B.O. eds), pp. 3-17. Wallingford: CAB International.

Scapigliati, G., Scalia, D., Marras, A., Meloni, S. \& Mazzini, M. (1999). Immunoglobin levels in the teleost sea bass (Dicentrarchus labrax L.) in relation to age, season and water oxygenation. Aquaculture 174, 207-212.

Schjolden, J., Stoskhus, S. \& Winberg, S. (2005). Does individual variation in stress responses and agonistic behavior reflect divergent stress coping strategies in juvenile rainbow trout? Physiological and Biochemical Zoology 78 (5), 715-723.

Schunck, O. (1980). Ergebnisse aus der Zier- und Versuchsfischpraxis. Kleintier Ptaxis 25, 1-56.

Scott, A. P., Pinillos, M., and Ellis, T. (2001). Why measure steroids in fish plasma when you can measure them in water? In Perspectives in Comparative Endrochrinology: Unity and Diversity. (Goos, Th.H.J., Rastogi, R.K., Vaudry, H., \& Pierantoni, R. eds), pp. 1291-1295. Bologna: Monduzzi Editore.

Shima, J.S. (2002). Mechanisms of density- and number dependent population regulation of a coralreef fish. Marine and Freshwater Research 53, 175-179.

Shimizu, T. and Karten, H. J. (1993). The avian visual system and the evolution of the neocortex. In Vision, Brain and Behaviour in Birds (Zeigler, H.P. \& Bischof, H.J. eds), pp. 104-114. Cambridge, MA: MIT Press.

Singer, P (1989). All animals are equal. In Animal Rights and Human Obligations. (Regan, T. \& Singer, P. eds), Englewood Cliffs: Prentice Hall.

Skjervold, P.O., Fjaera, P.B., Ostby, P.B. \& Einen, O. (2001). Live-chilling and crowding stress before slaughter of Atlantis salmon (Salmo salar). Aquaculture 192, 267-282.

Sneddon, L.U. (2002). Anatomical and electrophysiological analysis of the trigeminal nerve in a teleost fish, Oncorhynchus mykiss. Neuroscience Letters 319, 167-171.

Sneddon, L.U., Braithwaite, V.A. \& Gentle, M.J. (2003a). Do fish have nociceptors? Evidence for the evolution of a vertebrate sensory system. Proceedings of the Royal Society London B 270, 1115-1121.

Sneddon, L.U., Braithwaite, V.A. \& Gentle, M.J. (2003b). Novel object test: examining nociception and fear in the rainbow trout. Proceedings of the Royal Society 270, 1115-1121.

Sobchuck, M.S. \& Dawnson, N. (1988). Physiological response of walleye (Stizostedion vitreum) to hooking/holding stress. Ontario Fisheries Technical Report Series 25, 15.

Sørum, U. \& Damsgård, B. (2003). Effects of anaesthisation and vaccination on feed intake and growth of Atlantic salmon (Salmo salar L.). Aquaculture 232, 333-341.

Southgate, P. \& Wall, T. (2001). Welfare of farmed fish at slaughter. In Practice 23, 277-284. 
Sovrano, V.A. \& Bisazza, A. (2003). Modularity as a fish (Zenotoca eisen) views it: Conjoining and nongeometric information for special reorientation. Journal of Experimental Phychology 29, 199-210.

Strangeland, K., Hoie, S. \& Taksdal, T. (1996). Experimental induction of infectious pancreatic necrosis in Atlantic salmon (Salmo salar L.) post-smolts. Journal of Fish Diseases 19, 323327.

Sumpter, J. P. (1997). The endochrinology of stress. In Fish Stress and Health in Aquaculture, Society for Experiment Biology, Seminar Series 62. (Iwama, G.K., Pickering, A.D., Sumper, J.P., \& Schreck, C.B. eds), pp. 95-118. Cambridge: Cambridge University Press.

Sundstom, L.F., Peterson, E., Hojesjo, J., Jonsson, J.I. \& Jarvi, T. (2004). Hatchery selection promotes boldness in newly hatched brown trout (Salmo trutta): implications for dominance. Behavioural Ecology 15, 192-198.

Suski, C.D., Cooke, S.J., Killin, S.J., Wahl, D.H. \& Phipp, D.P. (2005). Behaviour of walleye, Sander vitreus, and largemouth bass, Micropterus salmoides, exposure to different wave intensities and boat operating conditions during livewell confinement. Fisheries Management and Ecology 12, 19-26. doi:10.1111/j.1365-2400.2004.00415.x

Sutor, H.C. \& Huntingford, F.A. (2002). Eye colour in juvenile Atlantic salmon: effects of social status, aggression and foraging success. Journal of Fish Biology 61: 606-614. doi:10.1111/j.1095-8649.2002.tb00899.x

Swaney, W., Kendal, J., Capon, H., Brown, C. \& Laland, K.N. (2001). Familiarity facilitates social learning of foraging behaviour in the guppy. Animal Behaviour 62, 591-598.

Tanck, M.W.T., Vermeulen, K.-J., Bovenhuis, H. \& Komne, J. (2001). Heredity of stress-related cortisol response in androgenic common carp (Cyprinus carpio). Aquaculture 199, 283-294.

Thorburn, M.A., Teare, G.F., Martin, S.W. \& Moccia, R.D. (2001). Group-level factors associated with chemotherapeutic treatment regiments in land-based trout farms in Ontario, Canada. Preventative Veterinary Medicine 50, 451-466.

Thorpe, J.E., Mangel, M., Metcalfe, N.B. \& Huntingford, F.A. (1998). Modelling the proximate basis of salmonid life history variation, with application to Atlantic salmon (Salmo salar L.). Evolutionary Ecology 12, 581-598.

Tierney, K.B. \& Farrell, A.P. (2004). The relationships between fish health, metabolic rate, swimming performance and recovery in return-run sockeye salmon, Oncorhynchus nerka (Walbaum). Journal of Fish Diseases 24, 663-671. doi:10.1111/j.1365-2761.1004.00590.x

Turnbull, J.F., Adams, C.E., Richards, R.H. \& Robertson, D.A. (1998). Attack site and resultant damage during aggressive encounters in Atlantic salmon (Salmo salar L.) parr. Aquaculture 159, 345-353. 
Turnbull, J.F., Bell, A., Adams, C.E., Bron, J. \& Huntingford, F. (2005). Stocking density and welfare of cage farmed Atlantic salmon: application of a multivariate analysis. Aquaculture 243 (1-4), 121-132.

Turner, J.W., Nemeth, R. \& Rogers, C. (2003). Measurement of fecal glucocorticoids in parrotfishes to assess stress. General and Comparative Endocrinology 133, 341-352.

UK Animals Act (1986). Guidance on the Operation of the Animals (Scientific Procedures) Act 1986. Presented to Parliament by the State for the Home Department pursuant to Eliz. II 1986 C. 14 Section 21 (Animals Scientific Procedures) Act 1986.

UK Farm Animal Welfare Council (2005). The Five Freedoms. Website http://www.fawe.org.uk/freedoms.htm (accessed on 11 April 2005).

USA Department of the Interior, Fish and Wildlife Service, U.S. Department of Commerce and U.S. Census Bureau (2001). National Survey of Fishing, hunting and Wildlife-Associated Recreation, pp. 170.

van de Vis, H., Kestin, S., Robb, D., Ochlensschlager, J., Lambooij, B., Munkner, W., Kuhlmann, H., Kloosterboer, K., Tejada, M., Huidobro, A., Ottera, H., Roth, B., Sorensen, N.K., Akse, L., Byrne, H., Byrne, H. \& Nesvadba, P. (2003). Is humane slaughter of fish possible for industry? Aquaculture Research 34, 211-220. doi:10.1046/j.1365-2109.2003.00804.x

Vazzana, M., Cammerata, M., Cooper, E.L. \& Parrinello, N. (2002). Confinement stress in sea bass (Dicentrarchus labrax) depresses peritoneal leukocyte cytotoxicity. Aquaculture 210, 231243.

Verheijen, F.J. \& Buwalda, R.J.A. (1988). Do pain and fear make a hooked carp in play suffer? CIP - GEGEVENS. Utrecht. ISBN 90-9002167-1.

Waring, C.P., Stagg, R.M. \& Poxton, M.G. (1992). The effect of handling on flounder (Platichthys flesus) and Atlantic salmon (Salmo salar L.). Journal of Fish Biology 41, 131-144.

Wedermeyer, G. A. (1997). Effects of rearing conditions on the health and physiological quality of fish in intensive culture. In Fish Stress and Health in Aquaculture, Society for Experiment Biology, Seminar Series 62. (Iwama, G.K., Pickering, A.D., Sumper, J.P., \& Schreck, C.B. eds), pp. 35-71. Cambridge: Cambridge University Press.

Weld, M.M., Fryer, J.N., Rivier, J. \& Lederis, K. (1987). Inhibition of CRF-and Urotensin I stimulated ACTH release from goldfish pituitary cell columns by the CRF analogue a-helix CRF-(9-41). Regulatory Peptides 19, 273-280.

Wendelar Bonga, S.E. (1997). The stress response in fish. Physiology Review 77, 591-625. 
Weyts, F.A.A., Cohen, N., Flik, G. \& Verburg-van Kemenade, B. (1999). Interactions between the immune system and the hypothalamo-pituitary-interrenal axis in fish. Fish \& Shellfish Immunology 9, 1-20.

Winfree, R.A., Kindschi, G.A. \& Shaw, H.T. (1998). Elevated water temperature, crowding and food deprivation accelerate fin erosion in juvenile steelhead. Progressive Fish-Culturist 60, 192199.

Wingfield, J.C. (2003). Control of behavioural strategies for capricious environments. Animal Behaviour 66, 807-815.

World Bank (2005). Saving Fish and Fishers: Toward Sustainable and Equitable Governance of the Global Fishing Sector. The World Bank. Washington, pp. 10.

Yildiz, H.Y. \& Pulatsu, S. (1999). Evaluation of the secondary stress response in healthy Nile tilapia (Oreochromis niloticus L.) after treatment with a mixture of formalin, malachite green and methylene blue. Aquaculture Research 30, 379-383. doi:10.1046/j.1265-2109.1999.00341.x

Yue, S., Moccia, R.D. \& Duncan, I.J.H. (2004). Investigating fear in domestic rainbow trout, Oncorhynchus mykiss, using an avoidance learning task. Applied Animal Behaviour Science, 87 (3-4), 343-354.

Zaccone, G., Fasula, S. \& Ainis, L. (1994). Distribution patterns of the paraneuronal endocrine cells in the skin, gills and the airways of fishes determined by immunohistochemical and histological methods. Histochemical Journal 26, 609-629. 